\title{
Purinergic receptors in the splanchnic circulation
}

\author{
Manuela Morato • Teresa Sousa • \\ António Albino-Teixeira
}

Received: 15 October 2007 / Accepted: 18 February 2008 / Published online: 29 April 2008

(C) Springer Science + Business Media B.V. 2008

\begin{abstract}
There is considerable evidence that purines are vasoactive molecules involved in the regulation of blood flow. Adenosine is a well known vasodilator that also acts as a modulator of the response to other vasoactive substances. Adenosine exerts its effects by interacting with adenosine receptors. These are metabotropic G-protein coupled receptors and include four subtypes, $A_{1}, A_{2 A}, A_{2 B}$ and $A_{3}$. Adenosine triphosphate (ATP) is a co-transmitter in vascular neuroeffector junctions and is known to activate two distinct types of P2 receptors, P2X (ionotropic) and P2Y (metabotropic). ATP can exert either vasoconstrictive or vasorelaxant effects, depending on the P2 receptor subtype involved. Splanchnic vascular beds are of particular interest, as they receive a large fraction of the cardiac output. This review focus on purinergic receptors role in the splanchnic vasomotor control. Here, we give an overview on the distribution and diversity of effects of purinergic receptors in splanchnic vessels. Pre- and post-junctional receptormediated responses are summarized. Attention is also given to the interactions between purinergic receptors and other receptors in the splanchnic circulation.
\end{abstract}

M. Morato $\cdot$ T. Sousa $\cdot$ A. Albino-Teixeira Institute of Pharmacology and Therapeutics, Faculty of Medicine and IBMC, University of Porto, Porto, Portugal

M. Morato $\cdot$ T. Sousa

Pharmacology Department, Faculty of Pharmacy,

University of Porto,

Porto, Portugal

A. Albino-Teixeira $(\bowtie)$

Faculty of Medicine of Porto,

Institute of Pharmacology and Therapeutics,

Alameda Prof. Hernâni Monteiro,

4200-319 Porto, Portugal

e-mail: albinote@med.up.pt
Keywords Adenosine receptors · purinergic .

$\mathrm{P} 2 \mathrm{X}$ receptors $\cdot \mathrm{P} 2 \mathrm{Y}$ receptors $\cdot$ Splanchnic vasculature

\section{Introduction}

Almost fifty years separate the first report of extracellular actions of purine nucleotides and nucleosides by Drury and Szent-Györgyi in 1929 [39] and the definition of purinergic receptors by Burnstock in 1976 [18]. In the last few decades, a lot of research has been made in what concerns purinergic receptors and it is nowadays established that extracellular nucleotides and nucleosides are released by cells to provide the primary components for purinegic responses [43]. Purinergic receptors are important regulators of the blood flow, since they mediate vasoconstriction, vasodilation and neurotransmitter release. The splanchnic circulation is composed of gastric, small intestinal, colonic, pancreatic, hepatic and splenic circulations, arranged in parallel with one another. The major arteries supplying the splanchnic organs are the celiac artery, the superior mesenteric artery and inferior mesenteric artery, which branch off from the aorta and give rise to smaller arteries that anastomose extensively. Splanchnic blood is drained to the liver via the portal vein, and flows from the liver to the inferior vena cava via the hepatic veins $[101,127]$. Since the splanchnic circulation receives about $25 \%$ of the cardiac output, alterations in the splanchnic circulation may have important clinical consequences. This review will foccus on the distribution and function of purinergic receptors particularly in vessels of the splanchnic circulation.

According to the IUPHAR Committee on Receptor Nomenclature and Drug Classification (NC-IUPHAR) [51], purinergic receptors comprise adenosine receptors and $\mathrm{P} 2$ receptors, given that their endogenous agonist is 
adenosine or adenosine triphosphate (ATP), respectively. P2 receptors are further divided in $\mathrm{P} 2 \mathrm{X}$ receptors, which are ionotropic ligand-gated ion channel receptors, and P2Y receptors, which are metabotropic G protein-coupled receptors.

There are four different adenosine receptors, denoted $A_{1}$, $A_{2 A}, A_{2 B}$, and $A_{3}$ [52]. All of them have been cloned in several different animal species, including human. Adenosine receptors are $\mathrm{G}$ protein-coupled receptors. Classically, they have been distinguished by those that couple to $G_{i}$ proteins, the adenosine $A_{1}$ and $A_{3}$ receptors, and those that are coupled to $G_{s}$ proteins, the adenosine $A_{2 A}$ and $A_{2 B}$ receptors. Nowadays, adenosine receptors are viewed as pleiotropic receptors since for the four of them there is evidence of distinct profiles of coupling to different $G$ proteins and to different transducing systems, according to their degree of activation and with their particular localization [52].

$\mathrm{P} 2 \mathrm{X}$ receptors are a family of seven proteins $\left(\mathrm{P}_{2} \mathrm{X}_{1-}\right.$ $\mathrm{P} 2 \mathrm{X}_{7}$ ) [77]. All $\mathrm{P} 2 \mathrm{X}$ receptors are ligand-gated ion channeltype, with almost equal permeability to $\mathrm{Na}^{+}$and $\mathrm{K}^{+}$, and significant permeability to $\mathrm{Ca}^{2+}$ [46]. The seven P2X subunits form functional receptors that are named homomeric P2X receptors when expressed alone or heteromeric P2X receptors if they result from the combination of different subunits. Often native cell types express multiple P2X subunit mRNA transcripts and multiple P2X subunits. It is not clear how many subunits are required in each heteromer, which ones dominate, or if a greater number of heteromers can be formed [78, 121, 163]. P2 $\mathrm{X}_{6}$ subunits form only heteromeric channels and $\mathrm{P} 2 \mathrm{X}_{7}$ subunits only homomeric channels [173]. P2X receptors form as multimeric assemblies of channel subunits. The exact stoichiometry of the receptor remains unclear although studies have suggested that the channel may be comprised of at least three subunits [163].

The family of the $\mathrm{P} 2 \mathrm{Y}$ receptors includes, for now, 14 different receptors. The $\mathrm{P}_{2} \mathrm{Y}_{1}, \mathrm{P}_{2} \mathrm{Y}_{2}, \mathrm{P}_{2} \mathrm{Y}_{4}, \mathrm{P}_{2} \mathrm{Y}_{6}, \mathrm{P} 2 \mathrm{Y}_{11}$, $\mathrm{P} 2 \mathrm{Y}_{12}$ and $\mathrm{P} 2 \mathrm{Y}_{13}$ receptors are the mammalian receptors, while the $\mathrm{P} 2 \mathrm{Y}_{3}, \mathrm{P} 2 \mathrm{Y}_{5}, \mathrm{P} 2 \mathrm{Y}_{7}, \mathrm{P}_{2} \mathrm{Y}_{8}, \mathrm{P}_{2} \mathrm{Y}_{9}$ and $\mathrm{P} 2 \mathrm{Y}_{10}$ receptors represent receptors cloned from non-mammalian vertebrates or receptors that are currently under functional characterization [1]. Based on (1) sequence homology, (2) the presence of key amino acids essential for receptor activation, (3) chromosomal colocalization, (4) similarity of the cognate ligand, and (5) identification of uridine diphosphate (UDP)-glucose in the extracellular space, the IUPHAR Subcommittee recently rename the UDP-glucose receptor the $\mathrm{P}_{2} \mathrm{Y}_{14}$ receptor [1].

$\mathrm{P} 2 \mathrm{Y}$ receptors are metabotropic $\mathrm{G}$ protein-coupled receptors and although P2Y receptors couple to specific G proteins, one given $\mathrm{P} 2 \mathrm{Y}$ receptor can couple to functionally distinct $G$ proteins and signalling pathways [2]. This provides the opportunity for agonist-specific signaling involving distinct active conformations of the receptor which raises the possibility of pursuing selective targets with therapeutic relevance. However, there are no studies on this issue in what concerns the splanchnic circulation. Pharmacologically, P2Y receptors can be subdivided into the adenine-nucleotide-preferring receptors mainly responding to adenosine diphosphate (ADP) and ATP (human and rodent $\mathrm{P} 2 \mathrm{Y}_{1}, \mathrm{P} 2 \mathrm{Y}_{12}$ and $\mathrm{P} 2 \mathrm{Y}_{13}$, and human $\left.\mathrm{P} 2 \mathrm{Y}_{11}\right)$, the uracil-nucleotide-preferring receptors (human $\mathrm{P}_{2} \mathrm{Y}_{4}$ and $\mathrm{P}^{2} \mathrm{Y}_{6}$ ) responding to either uridine triphosphate (UTP) or UDP, receptors of mixed selectivity (human and rodent $\mathrm{P}_{2} \mathrm{Y}_{2}$ and rodent $\mathrm{P} 2 \mathrm{Y}_{4}$ ), and receptors responding only to UDP-glucose and UDP-galactose $\left(\mathrm{P}^{2} \mathrm{Y}_{14}\right)$ [2].

\section{Adenosine receptors in the splanchnic circulation}

Despite the existence of several studies describing a role for adenosine in the regulation of splanchnic circulation $[48,55$, $87,118,150,151]$, there is little information concerning to adenosine receptors distribution in these vascular beds. Till now, expression of adenosine receptors in splanchnic vessels has been evaluated only in the mesenteric vasculature [36, 71]. Western-blot analysis and quantitative densitometry revealed that mesenteric microvessels from Wistar rats express all the adenosine receptors subtypes, i.e., $A_{1}, A_{2 A}$, $A_{2 B}$ and $A_{3}$ receptors. $A_{2 A}$ and $A_{3}$ receptors were found to be abundantly expressed in these vessels [71]. Similar results were also found by reverse transcriptase polymerase chain reaction (RT-PCR) studies in the Sprague Dawley rat mesenteric vascular bed, thus suggesting an important physiological role for $\mathrm{A}_{2 \mathrm{~A}}$ and $\mathrm{A}_{3}$ receptors in the regulation of intestinal blood flow [36]. Binding assays with selective ligands for $\mathrm{A}_{2 \mathrm{~A}}$ receptors also evidenced the presence of this receptor subtype in the rabbit mesenteric artery [31]. There are, however, some differences concerning to adenosine $A_{1}$ receptor expression. $A_{1}$ receptor protein appears to be significantly expressed in mesenteric microvessels from Wistar rats [71], while $A_{1}$ receptor mRNA was undetected in the mesenteric vascular bed from Sprague Dawley rats [36]. These contrasting results may be due to technique limitations or to differences between rat strains. It is also possible that the authors studied different segments of the mesenteric vascular bed. While Jackson et al [71] specified that $2 \mathrm{nd}$ and $3 \mathrm{rd}$ order branches of the mesenteric vasculature were used, Donoso et al [36] just refers to the mesenteric arterial bed. Moreover, the inclusion of sympathetic nerve fibers in the homogenate could also account for the discrepancy in the $\mathrm{A}_{1}$ receptor expression.

Table 1 summarizes the information on the distribution of adenosine receptors in vessels of the splanchnic circulation. 
Table 1 Distribution of adenosine receptors in vessels of the splanchnic circulation

\begin{tabular}{lllll}
\hline Adenosine Receptor & Preparation & Technique & Expression & Reference \\
\hline $\mathbf{A}_{\mathbf{1}}$ & Rat mesenteric microvessels & Western Blot and quantitative densitometry & Strongly expressed & {$[71]$} \\
& Rat mesenteric vascular bed & RT-PCR & Not detected & [36] \\
$\mathbf{A}_{\mathbf{2}}$ & Rat mesenteric microvessels & Western Blot and quantitative densitometry & Very strongly expressed & {$[36,71]$} \\
& Rat mesenteric vascular bed & RT-PCR & Strongly expressed & {$[31]$} \\
& Rabbit mesenteric artery & Binding assay & Low density & {$[71]$} \\
$\mathbf{A}_{\mathbf{2 B}}$ & Rat mesenteric microvessels & Western Blot and quantitative densitometry & Weakly expressed & {$[36]$} \\
& Rat mesenteric vascular bed & RT-PCR & Very strongly expressed & {$[71]$} \\
$\mathbf{A}_{\mathbf{3}}$ & Rat mesenteric microvessels & Western Blot and quantitative densitometry & Strongly expressed & {$[36]$} \\
\hline
\end{tabular}

\section{Effects mediated by adenosine receptors in the splanchnic circulation}

Considerable evidence indicates that adenosine acts as a modulator of sympathetic neurotransmission, exerting either inhibitory or facilitatory effects. The regulation of noradrenaline release by adenosine has been observed in several vascular (tail artery, saphenous vein, portal vein, mesenteric artery, hepatic artery, pancreatic-duodenal arteries) [14, 33, 68, 69, 176] and non-vascular tissues (kidney, adrenal medulla, vas deferens, heart) [42, 84, 132, 174, 186].

Adenosine inhibitory effect on noradrenergic transmission has been generally attributed to the activation of prejunctional $A_{1}$ receptors $[17,34,58,74,92,158]$. With respect to the splanchnic circulation, the majority of studies also points to a sympathoinhibitory role of adenosine mediated via $A_{1}$ receptors. In rabbit mesenteric arteries, adenosine and its analogs depressed neuroeffector transmission [68]. The rank order of potency of various agonists, R-N ${ }^{6}$-(phenylisopropyl-adenosine) (R-PIA) $\cong 5^{\prime}$-(N-ethylcarboxamido)-adenosine (NECA) $>\mathrm{S}^{-} \mathrm{N}^{6}$-(phenylisopropyladenosine) (S-PIA)>adenosine, suggested that these actions were mediated by $A_{1}$ receptors [68].

An $A_{1}$ receptor with a modulatory effect on sympathetic neurotransmission was also identified in other vessels and species. In the rabbit portal vein, adenosine also inhibited the contractile response evoked by adrenergic nerve stimulation via activation of presynaptic adenosine receptors of the $A_{1}$ subtype [14]. In the hamster mesenteric arterial bed, sympathoinhibition was also shown to be mediated by prejunctional $A_{1}$ receptors [136]. A similar role was also observed for this adenosine receptor subtype in the mesenteric artery from Wistar rat. Adenosine, chloroadenosine (CADO) and NECA inhibited noradrenaline release while the selective $A_{1}$ receptor antagonist, 1,3-dipropyl-8cyclopentylxanthine (DPCPX) significantly reduced the inhibition induced by adenosine or its analogs [153].

In contrast with the studies describing the involvement of prejunctional $A_{1}$ receptors in sympathoinhibition, Donoso et al. recently observed that $A_{2 A}$ and $A_{3}$ receptors reduced the noradrenaline overflow from the nerve terminals of the Sprague Dawley mesenteric arterial bed [36]. The additive inhibitory effects of selective $A_{2 A}$ and $A_{3}$ agonists and the significant increase in noradrenaline release elicited by the simultaneous blockade of $\mathrm{A}_{2 \mathrm{~A}}$ and $\mathrm{A}_{3}$ receptors, suggest that these receptors are also able to decrease sympathetic transmission. Furthermore, these receptors are markedly expressed in the rat mesenteric vascular bed [36]. In the rat portal vein, it was also described that the sympathoinhibitory effect of adenosine and its analogs is mediated by prejunctional adenosine receptors with characteristics of the $A_{2}$ subtype [75].

Despite ample evidence describing the adenosine ability to inhibit noradrenergic transmission, there is a lack of experimental data supporting a physiological role for endogenous adenosine as a modulator of sympathetic neurotransmission. In a rat model of prolonged sympathetic nerve stimulation associated with decreased tissue perfusion, the administration of 1,3-dipropyl-8-sulfophenylxanthine (DPSPX), a non selective antagonist of $\mathrm{A}_{1} / \mathrm{A}_{2}$ receptors, did not affect the mesenteric blood flow nor the noradrenaline spillover [83]. DPSPX also failed to attenuate noradrenergic neurotransmission during hemorrhagic hypotension [70]. Similar results were also observed in the hamster mesenteric arterial bed, where the application of DPCPX had no effect on contractile responses elicited by electrical field stimulation [136]. It has been described that activation of presynaptic $\alpha_{2}$-adrenoceptors reduces the inhibitory effect on noradrenaline release of $\mathrm{A}_{1}$-receptor activation $[4,15$, 91]. It is possible that, in splanchnic vascular beds, the adenosine inhibitory effect on transmitter release is revealed when presynaptic $\alpha_{2}$-adrenoceptors are blocked, as previously observed in other tissues [58, 61, 84]. These results suggest that endogenous adenosine may not reach a sufficient level to exert a physiological effect within the neuroeffector junction. However, it remains possible, that under pathophysiological conditions or in tissues with higher metabolic demand, endogenous adenosine may assume a significant role as a modulator of sympathetic neurotransmission. 
It is a well known fact that sympathetic neurons release both noradrenaline and ATP, which function as co-transmitters $[156,157]$. Examples of this adrenergic-purinergic cotransmission have also been observed in splanchnic vascular tissues such as mesenteric artery [181], mesenteric vein [155] and hepatic artery [12]. Activation of adenosine $A_{1}$ receptors by exogenous applied adenosine or its analogues has been shown to inhibit the release of both adrenergic and purinergic transmitters [38]. Moreover, the $\mathrm{A}_{1}$-receptor mediated inhibition of ATP release appears to be more pronounced than the inhibition of noradrenaline overflow [38]. Regarding the splanchnic circulation, in rabbit mesenteric arteries, the activation of presynaptic $A_{1}$ receptors by adenosine also seems to inhibit ATP release [68]. Furthermore, in canine splenic arteries, the continuous infusion of ATP inhibited both noradrenaline and ATP releases [187]. This inhibitory effect was attributed to the activation of $A_{1}$ receptors by adenosine readily generated from ATP and was partially reversed by the $\mathrm{A}_{1}$-adenosine receptor antagonist, 8phenyltheophylline [187].

In addition to its inhibitory action on adrenergic and purinergic neurotransmission, $\mathrm{A}_{1}$ receptors also appear to regulate non adrenergic non cholinergic transmission (NANC). The release of the NANC transmitter, calcitonin gene-related peptide, during perivascular nerve stimulation in rat mesenteric arterial bed was inhibited in the presence of adenosine receptor agonists and this effect was shown to be mediated by prejunctional $\mathrm{A}_{1}$ receptors [146]. This interpretation was based in the order of potency obtained for the adenosine receptor agonists tested, $\mathrm{N}^{6}$-ciclopentyladenosine $(\mathrm{CPA}) \geq \mathrm{R}-\mathrm{PIA} \geq \mathrm{NECA} \geq \mathrm{CADO} \geq \mathrm{S}$-PIA and in the effects obtained in the presence of selective $A_{1}$ or $A_{2}$ receptors antagonists (DPCPX and 3-[4-[2-[[6-amino-9[(2R,3R,4S,5S)5-(ethylcarbamoyl)-3,4-dihydroxy-oxolan-2-yl]purin2yl] amino]ethyl] phenyl]propanoic acid (CGS21680), respectively) [146].

Adenosine elicits vasodilatation in several splanchnic vessels, leading to an increase in blood flow and a decrease in vascular resistance. The vasorelaxant response to adenosine or its analogs has been observed in mesenteric, hepatic, gastric and pancreatic vascular beds $[23,24,87$, 102, 159,194]. The spleen circulation appears to be an exception, since the splenic arterial conductance was shown to be reduced in response to the administration of the adenosine analog, CGS21680 [120]. There is consensus that the vasodilatory effects of adenosine are mediated by $\mathrm{A}_{2}$ receptors. However, it is still a matter of debate which $A_{2}$ receptor subclass, i.e., $A_{2 A}$ or $A_{2 B}$, is involved in these vasorelaxant responses. In mesenteric vessels both $\mathrm{A}_{2 \mathrm{~A}}$ and $A_{2 B}$ receptors seem to contribute to vasodilatation. Indeed, it was previously observed that these $\mathrm{A}_{2}$ receptor subtypes are expressed in the mesenteric vascular bed, although $A_{2 B}$ receptors are weakly expressed in comparison to $A_{2 A}$ receptors [71]. $\mathrm{A}_{2 \mathrm{~A}}$ receptor-mediated vasodilatory effects have been observed in the rat and rabbit mesenteric artery $[31,64,79,133]$. These effects appear to involve the opening of potassium channels subsequent to $\mathrm{A}_{2 \mathrm{~A}}$ receptor activation. As previously referred, $A_{2}$ receptors are coupled to $G_{s}$ proteins, which activate adenylyl cyclase leading to an increase in intracellular cAMP. The elevation of cAMP further activates protein kinase $\mathrm{A}$, which opens potassium channels probably through a phosphorylation step [79].

A vasodilatory response to adenosine mediated by $A_{2 A}$ receptors was also observed in the portal vein and in the pancreatic vascular bed $[59,87]$.

In contrast, other studies in the rat mesenteric artery point to an $\mathrm{A}_{2 \mathrm{~B}}$-mediated vasodilatation, based on the potency order for NECA, adenosine and CGS21680 (NECA $>$ adenosine $>$ CGS21680). In these works, the selective $\mathrm{A}_{2 \mathrm{~A}}$ receptor antagonist failed to induce vasodilatation, unless high concentrations were used [131, 145]. $\mathrm{A}_{2 \mathrm{~B}}$ receptors seem to be primarily located on the smooth muscle. However, their contribution to vasodilatation appears to occur only in conditions of blockade of adenosine uptake. When the uptake is operational, adenosine and its analogs seem to activate a xanthine-resistant site which may be intracellular [131].

Adenosine-induced vasodilatation in splanchnic vessels appears to be dependent, at least in part, on the presence of a functional endothelium [167]. However, it does not seem to involve the release of nitric oxide (NO), since the vasodilatory response to adenosine or its analogs was not reduced by the blockade of NO synthesis in the isolated mesenteric artery and gastric resistance vessels [25, 64, 145].

Although it is well established that adenosine-induced vasodilation is mediated by $\mathrm{A}_{2}$ receptors, the administration of the selective $A_{1}$ antagonist, DPCPX, was shown to abolish the glucose-induced increase in pancreatic islet blood flow. This surprising finding suggests that $A_{1}$ receptors may also contribute to the vasorelaxant response in this vascular bed [22].

The magnitude of adenosine vasodilatory effects seems to vary with the caliber of the vessels. For instance, in the mesenteric arterial bed the pre-capillary arterioles showed the largest increases in diameter in response to adenosine, when compared to the effects in principal arterioles [103]. A similar effect was also observed in the venous side of the mesenteric circulation [103]. An opposite situation appears to occur in the hepatic vascular bed, where adenosine was shown to dilate the hepatic artery and the portal vein, but not the intrahepatic portal resistance vessels [23, 88].

Table 2 summarizes the information on the potencies of agonists and antagonists at adenosine receptors in the splanchnic circulation.

Just recently, the possibility of crosstalk between prejunctional facilitatory angiotensin II receptors and 
Table 2 Potencies of agonists and antagonists at adenosine receptors in the splanchnic circulation

\begin{tabular}{|c|c|c|c|c|c|c|c|c|}
\hline Agonist/Antagonist & $\mathrm{EC}_{50}(\mu \mathrm{M})$ & $\mathrm{EC}_{40}(\mu \mathrm{M})$ & $\mathrm{EC}_{30}(\mu \mathrm{M})$ & $\mathrm{pEC}_{50}$ & $\mathrm{pEC}_{40}$ & $\mathrm{pEC}_{20}$ & $\mathrm{pA}_{2}$ & Reference \\
\hline \multicolumn{9}{|l|}{ Adenosine receptors } \\
\hline 8-SPT & & & & & & & $5.63 \pm 0.26$ & {$[131]$} \\
\hline \multicolumn{9}{|c|}{ Adenosine $A_{1}$ receptor } \\
\hline \multirow[t]{3}{*}{ Adenosine } & & 4.7 & & & & & & {$[68]$} \\
\hline & & & & & & $5.8 \pm 0.1$ & & {$[136]$} \\
\hline & $14.9 \pm 4.0$ & & & & & & & [59] \\
\hline \multirow[t]{4}{*}{ NECA } & & 0.028 & & & & & & {$[68]$} \\
\hline & & & & & & $7.6 \pm 0.2$ & & [136] \\
\hline & $18.2 \pm 0.7$ & & & & & & & {$[146]$} \\
\hline & & & $0.15(0.02-0.42)$ & & & & & [153] \\
\hline \multirow[t]{2}{*}{ CADO } & $0.0267 \pm 0.001$ & & & & & & & {$[146]$} \\
\hline & & & $0.46(0.18-0.87)$ & & & & & [153] \\
\hline \multirow[t]{2}{*}{$\mathrm{CPA}$} & $0.00108 \pm 0.0009$ & & & & & & & {$[146]$} \\
\hline & & & & & & $7.5 \pm 0.1$ & & {$[136]$} \\
\hline \multirow[t]{2}{*}{ R-PIA } & $0.00186 \pm 0.0005$ & & & & & & & {$[68]$} \\
\hline & & 0.018 & & & & & & {$[146]$} \\
\hline \multirow[t]{2}{*}{ S-PIA } & $0.0366 \pm 0.0019$ & & & & & & & {$[68]$} \\
\hline & & 0.83 & & & & & & {$[146]$} \\
\hline \multicolumn{9}{|c|}{ Adenosine $A_{2 A}$ receptor } \\
\hline NECA & $0.06 \pm 0.02$ & & & & & & & {$[31]$} \\
\hline CGS21680 & $0.02 \pm 0.01$ & & & & & & & [31] \\
\hline CADO & $0.64 \pm 0.11$ & & & & & & & {$[31]$} \\
\hline ZM241385 & & & & & & & $7.65 \pm 0.25$ & [131] \\
\hline \multicolumn{9}{|c|}{ Adenosine $A_{2 B}$ receptor } \\
\hline \multirow[t]{2}{*}{ Adenosine } & & & & & $4.58 \pm 0.08$ & & & [131] \\
\hline & & & & & & & & [111] \\
\hline NECA & & & & $6.16 \pm 0.11$ & & & & [131] \\
\hline $\mathrm{CPA}$ & & & & & $4.54 \pm 0.12$ & & & [131] \\
\hline R-PIA & & & & $5.31 \pm 0.13$ & & & & [131] \\
\hline IB-MECA & & & & $5.38 \pm 0.06$ & & & & {$[131]$} \\
\hline \multicolumn{9}{|c|}{ Adenosine $A_{2 A} / A_{3}$ receptor } \\
\hline Adenosine & $0.2012 \pm 0.0342$ & & & & & & & {$[36]$} \\
\hline NECA & $0.0026 \pm 0.0009$ & & & & & & & [36] \\
\hline CGS21680 & $0.0035 \pm 0.0015$ & & & & & & & {$[36]$} \\
\hline $\mathrm{CPA}$ & $0.380 \pm 0.246$ & & & & & & & [36] \\
\hline IB-MECA & $0.0033 \pm 0.00085$ & & & & & & & {$[36]$} \\
\hline
\end{tabular}

Predominant receptor considered to be involved on the basis of functional data and receptor localization studies. Values \pm S.E.M. or $95 \%$ confidence interval (in parenthesis). $\mathrm{EC}_{50}, \mathrm{EC}_{40}$ and $\mathrm{EC}_{20}$ represent the molar concentration of the agonist nedded to cause $50 \%, 40 \%$ and $20 \%$ of the maximum response, respectively; $\mathrm{pEC}_{50}, \mathrm{pEC}_{40}$ and $\mathrm{pEC}_{20}$ are the negative logarithme to base 10 of the $\mathrm{EC}_{50}, \mathrm{EC}_{40}$ and $\mathrm{EC}_{20}$ of an agonist, respectively; $\mathrm{pA}_{2}$ is the negative logarithme to base 10 of the molar concentration of the antagonist that makes it necessary to double the concentration of the agonist nedded to elicit the original response. 8-sulphophenyltheophylline (8-SPT); N6-(3-iodo-benzyl)-adenosine$5 '-\mathrm{N}$-methyluronamide (IB-MECA); 5'-(N-ethylcarboxamido)-adenosine (NECA); chloroadenosine (CADO); $\mathrm{N}^{6}$-ciclopentyladenosine (CPA);

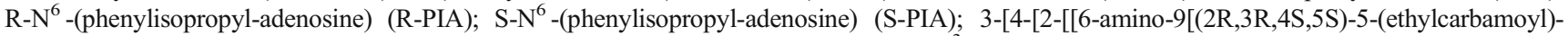
3,4-dihydroxy-oxolan-2-yl]purin2yl]amino]ethyl]phenyl]propanoic acid (CGS21680); [ $\left.{ }^{3} \mathrm{H}\right]-4-(2-[7-A m i n o-2-(2-f u r y l)[1,2,4]$ triazolo[2,3-a][1,3,5] triazin-5-ylamino]ethyl)phenol (ZM241385).

inhibitory adenosine and $\mathrm{P} 2$ receptors has emerged. It was described that in the rat mesenteric vein, but not in the artery, tonic activation of adenosine $\mathrm{A}_{1}$ receptors, but not $\mathrm{P} 2 \mathrm{X}$ receptors, amplify the facilitatory effect of angiotensin II on noradrenaline relase induced by electrical field stimulation [169]. Adenosine-angiotensin II interactions were also described in the mesenteric vasculature of rats chronically infused with DPSPX, a non selective antagonist of $A_{1} / A_{2}$ adenosine receptors [106]. These rats have been shown to develop hypertension, marked vascular hypertrophy and hyperplasia, activation of the renin-angiotensin system and altered vascular reactivity $[3,106,107,126$, 160]. Recently, it was described that the angiotensin II facilitatory effect on noradrenaline release was increased in mesenteric artery from DPSPX-treated rats. In contrast, the acute exposure of mesenteric vessels from control rats to 
DPSPX in vitro did not affect the facilitatory action of angiotensin II [106]. Also, in rat perfused mesentery intraarterial infusions of DPSPX did not alter the effects of intraarterial or intravenous angiotensin II on periarterial nerve stimulation or on vascular tone [66]. It is possible, however, that acute versus chronic blockade of adenosine receptors has different consequences and that the putative crosstalk is only evident after prolonged exposure to DPSPX. Further studies are needed to better characterize these interactions.

Portal hypertension results in both increased portal pressure and reduced splanchnic vascular resistance, leading to marked splanchnic hyperemia [141]. The pronounced arterial vasodilation and increased systemic and mesenteric artery blood flow observed in portal hypertension leads to systemic hypotension, despite an increased blood volume and cardiac output. The adenosine-mediated mesenteric vasodilation depends on a functional endothelium [32, 64, 167]. Adenosine vasodilation is commonly described to involve $A_{2 \mathrm{~A}}$ receptor activation, although $\mathrm{A}_{2 \mathrm{~B}}$ receptors may also play a role $[6,49,124]$. There is evidence of both $\mathrm{A}_{2 \mathrm{~A}}$ [64] or $\mathrm{A}_{2 \mathrm{~B}}$ receptor-mediated vasodilation [131, 145] in the mesenteric artery. Experimental differences (species, methodology) may explain the discordant information regarding to the adenosine receptor responsible for the relaxant response in mesenteric arteries of the rat [31]. An $\mathrm{A}_{2 \mathrm{~A}}$ receptor-mediated relaxation of mesenteric arteries can be observed in the rat, as described in the rabbit [31, 64]. The importance of this adenosine-induced vasodilation is further stressed by the fact that chronic blockade of adenosine receptors leads to hypertension [3].

The vascular responses to vasoactive agents are modified in portal hypertension [28, 53, 89]. The rabbit model of partial portal vein ligation to study portal hypertension is characterized by the development of portal-systemic shunting $[5,26]$. In rabbits with portal hypertension the vasodilation of the cranial mesenteric artery induced by adenosine is decreased both in vitro [30] and in vivo [100]. In portal hypertensive animals, there was mainly a decreased potency but also a decreased eficacy of all tested adenosine agonists compared to normal animals. Concomitantly, there was a decreased adenosine plasma level and a decreased binding density of $\left[{ }^{3} \mathrm{H}\right]-\mathrm{CGS} 21680$ and $\left[{ }^{3} \mathrm{H}\right]-4-$ (2-[7-Amino-2-(2-furyl)[1,2,4]triazolo[2,3-a][1,3,5]triazin5-ylamino]ethyl)phenol (ZM241385) to mesenteric artery membranes from portal hypertensive compared to normal rabbits [31]. The adenosine receptor responsible for the adenosine-induced relaxation of mesenteric arteries is of the $A_{2 A}$ subtype and the reduced density of these $A_{2 A}$ receptors may contribute for the reduced relaxant response to adenosine in the mesenteric arteries of portal hypertensive animals. Thus, de Brito et al. [31] hypothesized that hypertension-induced changes in the uptake and/or metabolism of plasma adenosine may have contributed for the significant decrease in adenosine plasma levels observed in their study. The most likely explanation for the observed decrease in the potency and eficacy of adenosine receptor agonists to induce mesenteric relaxation in portal hypertensive rabbits resides on the observed decreased density of adenosine $\mathrm{A}_{2 \mathrm{~A}}$ receptors.

\section{$\mathrm{P} 2 \mathrm{X}$ and P2Y receptors in the splanchnic circulation}

In 1993, Bo and Burnstock [7] provided direct evidence for the existence of P2X receptors in the vascular smooth muscle using a radioligand binding assay and autoradiography with $\left[{ }^{3} \mathrm{H}\right] \alpha$, $\beta$-methylene ATP $\left(\left[{ }^{3} \mathrm{H}\right] \alpha, \beta\right.$-meATP $)$. Already in this study, the authors reported regional and species differences in the distribution of $\mathrm{P} 2 \mathrm{X}$ receptors [7]: (1) medium- and small-sized arteries had higher densities than the elastic and large muscular arteries, and (2) in some large muscular arteries, such as the rabbit hepatic and mesenteric arteries, the outer region of the vessel had a higher density of receptors than the inner region. In the guinea-pig and rat portal veins, the longitudinal muscle has much higher densities of $\mathrm{P} 2 \mathrm{X}$ receptors than does the circular muscle, while in the rabbit portal vein the circular muscle has higher density of P2X receptors than the longitudinal muscle [7]. In the rabbit mesenteric vein, very low quantities of $\left[{ }^{3} \mathrm{H}\right] \alpha, \beta$-meATP were observed [7]. $\left[{ }^{3} \mathrm{H}\right] \alpha, \beta$-meATP is almost ineffective as an agonist at some $\mathrm{P} 2 \mathrm{X}$ receptors [165] and has a complex binding profile [104], which limits the interest of ligand-binding autoradiography using this ligand. Nevertheless, the results of Bo and Burnstock were further stressed and completed using different techniques, for the most part in the mesenteric vasculature. The presence of $\mathrm{P} 2 \mathrm{X}_{1}$-immunoreactivity was observed in the rat mesenteric artery [54, 60, 62, 90], but also in arterioles of the submucous plexus of the guinea-pig ileum [184] and in rat and mouse pancreatic vascular smooth muscle [29]. Conflicting results have been obtained in what concerns the venous part of the circulation. Hansen and co-workers [60] observed $\mathrm{P} 2 \mathrm{X}_{1}$-immunoreactivity in both the rat mesenteric artery and vein while Galligan and co-workers [54] described the presence of $\mathrm{P} 2 \mathrm{X}_{1}$-immunoreactivity in rat mesenteric arteries, but not in mesenteric veins. Using RT-PCR, mRNA of $\mathrm{P}_{2} \mathrm{X}_{1}$ receptors has been detected in rat hepatic [130] and mesenteric [129] arteries. However, there is a report of no detection of mRNA transcripts of $\mathrm{P} 2 \mathrm{X}_{1}$ receptors in the mesenteric artery of the rat [122]. Differences in the mesenteric arteries analysed can account for the conflicting results, since the former study used the superior mesenteric artery [122] while the latter study studied segments of superior and $2^{\text {nd }}$-order mesenteric arteries [129]. However, immunohistochemical analysis [57] revealed no major differences in the pattern of 
$\mathrm{P} 2 \mathrm{X}$ receptor isoform expression between the three sizes of vessel and may suggest that a novel additional subunit is expressed in large arteries.

Another pertinent question is where in the vascular wall are $\mathrm{P} 2 \mathrm{X}_{1}$ receptors located? In this way, the majority if not almost all, of the studies in which this issue was persecuted, have found $\mathrm{P} 2 \mathrm{X}_{1}$ receptors in the smooth muscle cell of the media [7, 29, 60, 90, 184]. Very recently, a study of Harrington and Mitchell [62] reported for the first time the presence of $\mathrm{P} 2 \mathrm{X}_{1}$-immunoreactivity in all the three layers of the rat mesenteric artery: not only in the smooth muscle cells of the media, but also in the adventia and in the endothelium. Curiously, the small $\mathrm{P} 2 \mathrm{X}_{1}$-receptor cluster identified by Hansen and co-workers was restricted to the adventitial surface of the media and to endothelial cells [60]. Opposedly to these studies, Lewis and Evans failed to detect $\mathrm{P} 2 \mathrm{X}_{1}$-immunoreactivity on the endothelium [90]. It seems that $\mathrm{P} 2 \mathrm{X}_{1}$ receptors are not located on nerves since they are still identified after destruction of the sympathetic nerves with 6-hydroxydopamine [60].

Some controversy exists concerning the distribution of $\mathrm{P} 2 \mathrm{X}_{2}$ receptors in the splanchnic circulation. RT-PCR studies showed that $\mathrm{P} 2 \mathrm{X}_{2}$ receptors are either absent [122] or weakly expressed in rat mesenteric artery and rat hepatic artery [130]. In contrast, immunohistochemistry studies identify the presence of $\mathrm{P} 2 \mathrm{X}_{2}$ receptors in the nerves and endothelial cells of the rat mesenteric artery and vein [60], in nerve fibers of the perivascular plexuses of the guineapig ileum [184] and also in the smooth muscle of the rat mesenteric artery and vein [60] and pancreatic vascular bed [29]. Interestingly, two splice variants of the $\mathrm{P} 2 \mathrm{X}_{2}$ receptors have been identified in rat coronary artery and aorta [122].

Regarding the other $\mathrm{P} 2 \mathrm{X}$ receptors, the $\mathrm{P} 2 \mathrm{X}_{3}$ receptor is weakly expressed both in the rat hepatic [130] and mesenteric [129] arteries. In contrast, the $\mathrm{P}_{2} \mathrm{X}_{4}$ and the $\mathrm{P} 2 \mathrm{X}_{7}$ receptors are reported to be very strongly expressed in the rat hepatic [130] and mesenteric [129] arteries, although some authors described no detection of $\mathrm{P}_{2} \mathrm{X}_{4}$ mRNA transcripts [122]. The $\mathrm{P}_{2} \mathrm{X}_{5}$ receptor is strongly expressed in the rat hepatic artery [130] but weakly expressed in rat mesenteric artery [129]. Till now, the $\mathrm{P}_{2} \mathrm{X}_{6}$ receptor was never detected in the splanchnic vasculature [129, 130].

In summary, with the exception of the $\mathrm{P}_{2} \mathrm{X}_{6}$ receptor, all the other $\mathrm{P} 2 \mathrm{X}$ receptors are expressed in the splanchnic circulation, at least in arteries. $\mathrm{P} 2 \mathrm{X}_{1}, \mathrm{P} 2 \mathrm{X}_{4}, \mathrm{P} 2 \mathrm{X}_{5}$ and $\mathrm{P} 2 \mathrm{X}_{7}$ receptors are strongly expressed while $\mathrm{P} 2 \mathrm{X}_{2}$ and $\mathrm{P} 2 \mathrm{X}_{3}$ receptors are weakly expressed. This difference may be associated with the particular role that each $\mathrm{P} 2 \mathrm{X}$ receptor plays in the splanchnic circulation. However, functional studies only evidence the major role of $\mathrm{P}_{2} \mathrm{X}_{1}$ receptor in mediating arterial vasoconstriction (see below). Even the late slow and sustained relaxation observed in response to ATP has been suggested to be mediated by $\mathrm{P} 2 \mathrm{X}_{1}$ receptors (see below). Further studies are required to conclude about this issue since although it is now possible to block gene expression and raise mice with deletion of $\mathrm{P} 2$ receptors, the study of the P2X receptors is still held back by the lack of potent and selective antagonists.

Not so much information exists concerning the distribution of P2Y receptors in splanchnic vessels. In general, P2Y receptors are found both on vascular endothelial and smooth muscle cells [40, 138]. RT-PCR studies found mRNA fragments for $\mathrm{P} 2 \mathrm{Y}_{1}, \mathrm{P} 2 \mathrm{Y}_{2}$ and $\mathrm{P} 2 \mathrm{Y}_{6}$ receptors in the rat [21] and mouse [177] mesenteric arteries, while $\mathrm{P}_{2} \mathrm{Y}_{4}$ mRNA wasn't detected [21]. Moreover, $\mathrm{P} 2 \mathrm{Y}_{1^{-}}$and $\mathrm{P} 2 \mathrm{Y}_{2}$-immunoreactivity was present in the smooth muscle of the rat pancreatic vascular bed [29]. Functional studies identify the presence of $\mathrm{P} 2 \mathrm{Y}_{1}$ receptors in the rat mesenteric vein [54] and $\mathrm{P} 2 \mathrm{Y}_{2}$ receptors in the guinea pig mesenteric vein [116].

Table 3 summarizes the information on the distribution of P2-purinoceptors in vessels of the splanchnic circulation.

\section{Effects mediated by $\mathrm{P} 2 \mathrm{X}$ and $\mathrm{P} 2 \mathrm{Y}$ receptors in the splanchnic circulation}

The previous notion that noradrenaline was the single sympathetic neurotransmitter in vascular neuroeffector junctions has given place to the actual fact that ATP is a co-transmitter at this synapses [180]. In what concerns the splanchnic circulation, the first description of such corelease was reported by $\mathrm{Su}$ [164] in the rabbit portal vein. Since then, growing evidence emerged that ATP is a cotransmitter in the splanchnic circulation of the dog $[9,94$, $113,114,144,170]$, rabbit [140, 181], guinea-pig [8], and rat [19, 37, 44].

The co-release of noradrenaline and ATP from sympathetic nerve terminals may be subject to separate modulatory mechanisms. Differential autoinhibition has been suggested in the rat mesenteric artery [41]. In the rabbit ileocolic artery, activation of presynaptic $\alpha_{2}$-adrenoceptors preferentially inhibits the release of noradrenaline [16]. In canine splenic arteries, adrenergic neuron blockade with guanethidine [189] or inhibition of sodium channels by tetrodotoxin [188] mainly depresses the adrenergic rather than the purinergic component. Opposing to this, the purinergic component is depressed, rather than the adrenergic component, after irreversible degeneration of adrenergic nerve fibres due to cold storage [190] or with dipyridamole [119]. Electrochemical and electrophysiological studies have also tried to clarify whether noradrenaline and ATP are co-stored and/or co-released. In vascular tissues not belonging to the splanchnic circulation, it seems that noradrenaline and ATP are released in parallel [110, 111], although these results are still controversal [109]. This 
Table 3 Distribution of P2-purinoceptors in vessels of the splanchnic circulation.

\begin{tabular}{|c|c|c|c|c|}
\hline P2 Receptor & Preparation & Technique & Expression & Reference \\
\hline \multirow[t]{10}{*}{$\mathbf{P} 2 \mathbf{X}_{1}$} & \multirow[t]{6}{*}{ Rat mesenteric artery } & Immunohistochemistry & Yes & {$[60]$} \\
\hline & & Immunohistochemistry & Yes & {$[90]$} \\
\hline & & Immunohistochemistry & Yes & {$[54]$} \\
\hline & & Immunohistochemistry & Yes & {$[62]$} \\
\hline & & RT-PCR & Yes & [129] \\
\hline & & RT-PCR & None & {$[122]$} \\
\hline & Rat hepatic artery & RT-PCR & Yes & {$[130]$} \\
\hline & Rat mesenteric vein & Immunohistochemistry & Yes & {$[54,60]$} \\
\hline & Guinea-pig arterioles of the ileum submucous plexus & Immunohistochemistry & Yes & [184] \\
\hline & Rat and mouse pancreatic vascular bed & Immunohistochemistry & Yes & [29] \\
\hline \multirow[t]{5}{*}{$\mathbf{P} 2 \mathbf{X}_{2}$} & \multirow[t]{2}{*}{ Rat mesenteric artery and vein } & \multirow[t]{3}{*}{ Immunohistochemistry } & Low density & {$[60]$} \\
\hline & & & Strongly stained & [29] \\
\hline & Rat and mouse pancreatic vascular bed & & None & {$[122]$} \\
\hline & Rat mesenteric artery & \multirow[t]{2}{*}{ RT-PCR } & Weak & [129] \\
\hline & Rat hepatic artery & & Weak & {$[130]$} \\
\hline \multirow[t]{2}{*}{$\mathbf{P}^{2} \mathbf{X}_{3}$} & Rat hepatic artery & \multirow[t]{2}{*}{ RT-PCR } & Weakly expressed & {$[130]$} \\
\hline & Rat mesenteric artery & & Weakly expressed & [129] \\
\hline \multirow[t]{3}{*}{$\mathbf{P} 2 \mathbf{X}_{4}$} & Rat hepatic artery & \multirow[t]{3}{*}{ RT-PCR } & Strongly expressed & {$[130]$} \\
\hline & Rat mesenteric artery & & Very strongly expressed & [129] \\
\hline & & & Not expressed & {$[122]$} \\
\hline \multirow[t]{2}{*}{$\mathbf{P}^{2} \mathbf{X}_{5}$} & Rat hepatic artery & \multirow[t]{2}{*}{ RT-PCR } & Strongly expressed & {$[130]$} \\
\hline & Rat mesenteric artery & & Weakly expressed & {$[129]$} \\
\hline $\mathbf{P} 2 \mathbf{X}_{6}$ & Rat hepatic and mesenteric arteries & RT-PCR & Never detected & {$[129,130$} \\
\hline \multirow[t]{2}{*}{$\mathbf{P} 2 \mathbf{X}_{7}$} & Rat hepatic artery & \multirow[t]{2}{*}{ RT-PCR } & Strongly expressed & {$[130]$} \\
\hline & Rat mesenteric artery & & Strongly expressed & [129] \\
\hline \multirow[t]{5}{*}{$\mathbf{P} 2 \mathrm{Y}_{12}$} & Rat mesenteric artery & RT-PCR & Yes & {$[21]$} \\
\hline & Mouse mesenteric artery & RT-PCR & Yes & {$[177]$} \\
\hline & Rat and mouse pancreatic vascular bed & Immunohistochemistry & Yes & [29] \\
\hline & Rat mesenteric vein & \multirow[t]{2}{*}{ Functional study } & Yes & {$[54]$} \\
\hline & Guinea pig mesenteric vein & & Yes & {$[116]$} \\
\hline $\mathrm{P}_{2} \mathrm{Y}_{4}$ & Rat mesenteric artery & RT-PCR & None & {$[21]$} \\
\hline \multirow[t]{2}{*}{$\mathbf{P} 2 \mathrm{Y}_{6}$} & Rat mesenteric artery & RT-PCR & Yes & {$[21]$} \\
\hline & Mouse mesenteric artery & RT-PCR & Yes & {$[177]$} \\
\hline
\end{tabular}

hypothesis of different storage has also been put into discussion in the rat mesenteric artery [41]. Differences in the methods used to quantify noradrenaline and ATP may account for the ambiguos results since the electrochemically measured noradrenaline may originate from both "small" and "large" dense cored vesicles, whereas excitatory junction potentials are believed to result only from ATP released from "small" dense cored vesicles [162].

It is generally accepted that periarterial nerve stimulation at low frequencies mostly causes a release of purinergic transmitter whereas stimulation at high frequencies mainly induces a release of adrenergic transmitter [142-144, 187, 192]. Modulation of ATP release by noradrenaline can only be revealed during nerve stimulation of very low frequencies $(0.2 \pm 2 \mathrm{~Hz})$ and short duration $(10 \mathrm{~s})[9,117]$. Parallel with what has been described on transmitter release, the neurogenic contractions induced by electrical field stimulation of postganglionic sympathetic nerves within splanchnic vessels are biphasic $[16,94,144,154]$. In dog [115] and rabbit mesenteric arteries [181], the first component is purinergic in nature, develops rapidly, is transient and predominates at low frequencies $(1-2 \mathrm{~Hz})$ of stimulation, whereas the second component is adrenergic, develops after the purinergic one, is more long-lasting and becomes more evident as the frequency of stimulation increases $(10 \mathrm{~Hz})$. Based on these findings, it was speculated that the purinergic component is involved more dominantly in the early phase of the total response, while the adrenergic component mainly contributes to the latter phase [115]. The fact that exogenous ATP produces a rapid and transient contraction and mimicked the neurogenic purinergic response suggested that the profile of neurogenic purinergic transmission reflects postjunctional rather than prejunctional mechanisms [115]. However, it has also been suggested that ATP released from the endothelium may function as a modulator of sympathetic neurotransmission and contribute to the purinergic constriction component, since the removal of the endothelium decreased the 
purinergic component but not the adrenergic component of the vasoconstrictor responses to stimulation [191]. Functionally, neurogenic released ATP evokes biphasic responses on the vascular smooth muscle: initially direct excitatory junction potentials followed by indirect hyperpolarization through the release of endothelium-derived hyperpolarizing factor (EDHF) [172]. Interestingly, there is a report of ATP being partially responsible for the neurogenic NANC endothelium-independent relaxation of the longitudinal muscle of the rabbit portal vein [13]. This ATP-mediated neurogenic relaxation seems to come about via $\mathrm{P} 2$ receptors located on the smooth muscle $[13,76]$. A study suggested that the sympathetic purinergic contractile responses of the dog mesenteric artery may be caused by an unknown substance selective to P2X-purinergic receptors, rather than ATP [114]. Alternatively, neurogenically released ATP may act only on the P2X-purinergic receptors, unlike exogenously ATP [114].

An important point concerning differential proportions of the purinergic and adrenergic components of the sympathetic neurotransmission refers to the calibre of the vessels in question. This issue is effectively evaluated in the mesenteric vasculature where it is possible to study vessels with quite different internal diameters. It is generally agreed that the importance of the purinergic component increases and that of the adrenergic component decreases with the reduction of the size of the mesenteric arteries [56, 93]. If one thinks that in small mesenteric arteries the neurogenic purinergic component of the periarterial nerve stimulation dominates [56, 93], that small mesenteric arteries are more sensible to $\alpha, \beta$-meATP and UTP than large arteries [57], and even more, that in small (but not large) mesenteric arteries both $\mathrm{P} 2 \mathrm{X}_{1}$ and $\mathrm{P} 2 \mathrm{Y}_{2}$ receptors are found (see references below), it makes sense that neurally released ATP in this small vessels induces an immediately direct vasoconstriction, through activation of $\mathrm{P} 2 \mathrm{X}_{1}$ receptors and a later indirect endothelium-dependent vasorelaxation via activation of $\mathrm{P}_{2} \mathrm{Y}_{2}$ receptors and the release of EDHF [172].

Sympathetic cotransmission also seems be dependent on the species and/or regional tissue studied. As previously pointed out, the majority of the studies show that low frequencies of stimulation favour purinergic neurotransmission while high frequencies promote adrenergic neurotransmission [142, 143, 187, 192]. A variation was found in the canine gastroepiploic [170] and splenic artery [192]. In these preparations, the first phase is mediated by P2X receptors at low frequencies of stimulation, but also presynaptic $\alpha$-adrenoceptors at high frequencies, while the second phase response involves mostly $\alpha_{1}$-adrenoceptors and partially $\mathrm{P} 2 \mathrm{X}$ receptor activations at all frequencies used. Uniquely, electrical stimulation (100 pulses, $10 \mathrm{~Hz})$ of the guinea-pig submucosal arterioles caused vasoconstiction mediated by activation of $\mathrm{P} 2 \mathrm{X}$ receptors by ATP or a related purine nucleotide [47]. The functional role of neurally released noradrenaline in this tissue appears to be restricted to its prejunctional modulation of transmitter release [47].

The electrical and contractile response elicited with stimulation of sympathetic nerves has been shown to differ significantly between arteries and veins. For instance, in the guinea-pig mesenteric artery, sympathetic nerve stimulation gives rise to rapidly rising excitatory junction potentials of brief duration that are resistant to prazosin, but are blocked by $\alpha, \beta$-meATP $[67,82]$. In contrast, in the guinea-pig mesenteric vein a slow depolarization [166] that is resistant to purinoceptor desensitization with $\alpha, \beta$-meATP $[65,67]$ is observed rather than fast EJPs. This has led to the conclusion that ATP is not involved in these junctional events $[65,67]$ and, hence, is not released during nerve stimulation. However, a study on guinea-pig mesenteric vessels [155] revealed that arterial contractile response to sympathetic nerve stimulation is due exclusively to noradrenaline, whereas at least three different neurotransmitters (noradrenaline, ATP and neuropeptide Y) appear to contribute to the venous neural response. In another study, electric field stimulation induced ATP overflow in the guinea-pig mesenteric vein [8]. The difference in the contribution of ATP to the neural response in artery and vein was suggested to be related to the presence of different populations of ATP receptors, i.e., in artery, rapidly desensitizing $\mathrm{P}_{2} \mathrm{X}_{1}$ receptors predominate whereas in vein, non-desensitizing P2Y receptors predominate [116]. However, the apparent contradictory results between these different studies $[67,82,155]$ may also be ascribed to differences in the methodological approaches (evaluation of membrane potentials by electrophysiology vs contractile and $\left[{ }^{3} \mathrm{H}\right]$-noradrenaline release studies) or to the size of the vessels studied (the studies of Kreulen [82] involved a broader range of internal diameters of the vessels). Besides, there might be differences in the postjunctional effects of prejunctionally released neurotransmitters, as it is suggested to occur in the human saphenous vein [147], where ATP is co-released with noradrenaline but did not appear to generate the non-adrenergic component of contraction. In the guinea-pig, release of both ATP and noradrenaline in mesenteric veins exceeds release in arteries [8]. Differently, in the dog, release of noradrenaline in veins exceeds release of noradrenaline in arteries, whereas both vessels release equal amount of ATP [9].

Whether ATP by itself or indirectly after degradation to adenosine modulates sympathetic neurotransmission is another point of interest in the context of this review. Inhibition of sympathetic neurotransmission via prejunctional $\mathrm{P} 2$ receptors has been described in a number of tissues from rat and mouse [182] although little investigation has pursuit this issue in the splanchnic vasculature. In 
the dog mesenteric artery $\alpha \beta$-meATP had no effect on $\left[{ }^{3} \mathrm{H}\right]$ noradrenaline release, suggesting that the $\mathrm{P} 2$ purinoceptor is absent or not functioning in the sympathetic nerve terminals [115]. In the rat mesenteric artery, ATP inhibition of noradrenaline release occurs without the conversion of ATP to adenosine [153]. However, the inhibition was completely abolished by DPCPX, an antagonist of adenosine $\mathrm{A}_{1}$ receptors, and pyridoxal-phosphate-6-azophenyl-2',4'disulphonic acid (PPADS), an antagonist of P2 receptors, suggesting that that the receptor involved may be different from the well known adenosine $\mathrm{A}_{1}$ or P2-receptors [153]. On the contrary, in the hamster mesenteric arterial bed, prejunctional adenosine $\mathrm{A}_{1}$, but not $\mathrm{P} 2$, receptors modulate sympathetic neurotransmission [136]. The purinergic component of sympathetic neurotransmission does not contribute significantly to sympathetic contractile responses of this vascular bed [136, 139]. It was suggested that inhibitory P2 receptors are expressed selectively on sympathetic nerves utilizing ATP as a cotransmitter, in accordance with the view that prejunctional P2 receptors on sympathetic nerve terminals are release-modulating autoreceptors [178, 183]. Another possibility is that endothelium-derived factors released upon activation of endothelial UTP-sensitive P2Y receptors inhibit ATP release from purinergic nerves in the smooth muscle cells of hamster mesenteric artery [171].

ATP elicits arterial contraction through stimulation of P2X receptors in the mesenteric artery of the rat $[54,73,85$, 123, 137], guinea-pig [116] and rabbit [20], and in the rat hepatic artery [130] and the guinea-pig portal vein [125]. The $\mathrm{P} 2 \mathrm{X}_{1}$ subtype is the receptor responsible for the purine nucleotides-induced arterial contractions [54, 177]. In contrast to what is observed in the arteries, venoconstriction is mainly mediated by $\mathrm{P}_{2} \mathrm{Y}_{2}$ receptors [54, 116, 123], although $\mathrm{P}_{2} \mathrm{Y}_{1}$ receptors (and possibly $\mathrm{P}_{2} \mathrm{Y}_{4}$ and $\mathrm{P}_{2} \mathrm{Y}_{6}$ receptors) and to smaller extent $\mathrm{P} 2 \mathrm{X}_{1}$ receptors [116] may also play a role. In the perfused rat mesenteric artery, a residual contractile response to ATP was observed after exposure to P2X antagonists [123]. Also, in isolated 2ndorder rat mesenteric arteries UTP-induced contractions persisted after desensitization of $\mathrm{P}^{2} \mathrm{X}_{1}$ receptors [54]. These studies suggest that other $\mathrm{P} 2$ receptor(s), probably $\mathrm{P}_{2} \mathrm{Y}_{2}$ receptors, contribute to the arterial contractile effect of purine nucleotides although playing a minor role [54, 123]. A P2Y receptor-mediated contractile effect has been described previously although not in the splanchnic circulation $[63,149,179]$. More recently, a study in mesenteric arteries from $\mathrm{P} 2 \mathrm{X}_{1}-\mathrm{KO}$ mice revealed that although $\mathrm{P} 2 \mathrm{X}_{1}$ receptors underlie an important component of the sympathetic neurogenic contraction, UTP and ADP, but not ATP, evoked concentration-dependent arterial contraction [177], suggesting the presence of a UTP- and UDP-sensitive P2Y receptor. These authors propose the $\mathrm{P}_{2} \mathrm{Y}_{6}$ receptor as a candidate for mediating this sustained vasoconstriction
[177]. However, a very recent work of the same group [86] concluded that $\mathrm{P} 2 \mathrm{X}_{1}$ receptors are required to generate the junctional calcium transients that activate this component of the neurogenic contraction, since they were not observed in $\mathrm{P} 2 \mathrm{X}_{1}-\mathrm{KO}$ mice. This observation doesn't exclude the possibility raised in previous studies of $\mathrm{P} 2 \mathrm{X}_{1}$ receptors being the principal mediators of purinergic contraction with other receptors playing minimal roles. In line with the view that both $\mathrm{P} 2 \mathrm{X}$ and $\mathrm{P} 2 \mathrm{Y}$ receptors participate in vasocontraction is the study of Lagaud and coworkers [85]. These authors described that both P2X- and $\mathrm{P} 2 \mathrm{Y}$-receptor mediated arterial contractions through different mechanisms. P2X receptors are activated by low concentrations of ATP ( $\mu \mathrm{M}$ range) and induce depolarization of the cell leading to the opening of voltage-dependent $\mathrm{Ca}^{2+}$ channels and direct calcium influx. Additionally, P2Ypurinoceptors are activated by high concentrations of ATP (mM range) which promote first a calcium influx through activation of a PTX-sensitive G protein and a dihydropyridinesensitive mechanism, and secondly a release of calcium from intracellular stores via the phospholipase C/IP3 pathway. In contrast, a study in the guinea-pig small mesenteric arteries couldn't observe P2X-mediated effects [108]. The dissimilar results obtained concerning the exclusivity of $\mathrm{P} 2 \mathrm{X}_{1}$ receptors or the result of both $\mathrm{P} 2 \mathrm{X} / \mathrm{P} 2 \mathrm{Y}$ receptors in mediating purinergic contraction probably reflect differences between species, as previously suggested [177].

The seven P2X subunits can form functional homomeric or heteromeric P2X receptors (see Introduction). The finding of mRNA for some P2X receptors with no evidence for a functional role [130] and the pharmacology evidence for some yet ununidentified P2X receptors $[57,175]$ has been suggesting that arteries may express heteromeric P2X receptors with properties dominated by the $\mathrm{P} 2 \mathrm{X}_{1}$ receptor subunit. The blood pressure of $\mathrm{P}_{2} \mathrm{X}_{1}$ receptor-deficient mice was normal or slightly elevated [112], suggesting that $\mathrm{P} 2 \mathrm{X}_{1}$ receptors may not be essential for the expression of arterial P2X receptors, although $\mathrm{P} 2 \mathrm{X}$ receptors are not the only receptors that regulate blood pressure levels. On the contrary, in $\mathrm{P} 2 \mathrm{X}_{1}-\mathrm{KO}$ mice ATP-mediated vasoconstrictions were abolished [177], suggesting that $\mathrm{P} 2 \mathrm{X}_{1}$ receptor subunit is essential for the production of functional P2X receptors. However, one has to consider the possibility that there is compensation of other $\mathrm{P} 2 \mathrm{X}$ receptors in these animals.

Activation of endothelial P2Y receptors causes arterial dilation [137]. This vasodilation is probably mediated by $\mathrm{P}_{2} \mathrm{Y}_{1}$ and $\mathrm{P} 2 \mathrm{Y}_{2}$ receptors, through hyperpolarization of the endothelium that correlates with endothelium-dependent vasodilation [105]. This P2Y receptor-induced endotheliummediated vasodilation occurs through the release of $\mathrm{NO}$, via the NO/cGMP pathway [21], and cyclo-oxigenase metabolites $[97,105]$ but also via the release of $\operatorname{EDHF}[97,98,99$, 
105, 148]. In fact, EDHF-mediated vasodilation seems to be the predominant mediator of $\mathrm{P} 2$ receptor-mediated regulation of perfusion pressure in the small arteries of the peripheral circulation [96, 172]. Both NO- and EDHF-mediated vasodilation can be induced by activation of $\mathrm{P} 2 \mathrm{Y}_{1}, \mathrm{P} 2 \mathrm{Y}_{2}$ and $\mathrm{P}_{2} \mathrm{Y}_{4}$, but not $\mathrm{P} 2 \mathrm{Y}_{6}$, receptors [95-98].

Some important features are associated with the endothelial P2Y-induced EDHF-mediated vasodilation. First, it is not observed in all vessels. Malmsjo an co-workers [97] reported that it occurs in the rat mesenteric artery but not in the carotid artery. Second, it depends on the resting tone of the vessel. In rat mesenteric arteries it was only observed in arteries which were under a low resting tone $(1 \mathrm{mN})$ [97]. Finally it may vary dramatically according to the vessel's internal diameter. $\mathrm{P} 2 \mathrm{Y}_{2}$ receptor-induced EDHF-mediated relaxation was clearly evident in large diameter main branch of the rat mesenteric artery (internal diameter of about $1.24 \mathrm{~mm}$ ) but almost absent in the rat small mesenteric arteries (internal diameter of about $340 \mu \mathrm{m}$ ) [105]. In another study [172], electrical stimulation or adventitial application of ATP induced endothelium-dependent hyperpolarization in thin hamster mesenteric arteries (internal diameter $<150 \mu \mathrm{m}$ ) but not in thick arteries (internal diameter $>300 \mu \mathrm{m}$ ). Usually, the importance of EDHF versus nitric oxide generally increases as the vessel diameter is reduced [152]. The results of Thapaliya and co-workers are more coherent with this view. However, as the stimulus was electrical stimulation or adventitial application of ATP, the higher number of smooth muscle cell layers was probably determinant for the absence of hyperpolarization in thick mesenteric arteries. This hypothesis is reinforced by the fact that intimal application of ATP could induce endothelium hyperpolarization [172]. In what concerns the study of Mistry and coworkers, differences in the distribution and/or transduction signalling of the endothelial $\mathrm{P} 2 \mathrm{Y}_{2}$ receptors, a counteracting effect of constrictor $\mathrm{P}_{2} \mathrm{Y}_{2}$ receptors in the smooth muscle cell or other $\mathrm{P} 2$ receptors, namely $\mathrm{P} 2 \mathrm{X}$ receptors, could mask the vasodilatory effect in small mesenteric arteries. Indeed, activation of $\mathrm{P} 2 \mathrm{X}$ receptors counteracts the hyperpolarization of vascular smooth muscle cells mediated by P2Y-induced release of EDHF [98, 99] but not NO [96]. Furthermore, species differences may also account for the different profile of the two studies. Curiously, in arteries of about $350 \mu \mathrm{m}$, neither electrical stimulation or adventitial administration of ATP induced hyperpolarization [172] nor stimulation os $\mathrm{P} 2 \mathrm{Y}_{2}$ receptors with ATP $\gamma \mathrm{S}$ caused vasodilation [105].

At a glance, it seems that the effects of ATP on the vasculature are quite clear-cut. $\mathrm{P} 2 \mathrm{X}$ receptors, namely $\mathrm{P} 2 \mathrm{X}_{1}$ present on vascular smooth muscle cells, are responsible for the ATP-induced vasoconstriction, while P2Y receptors, mainly $\mathrm{P}_{2} \mathrm{Y}_{2}$ located on vascular endothelial cells, mediate ATP-induced vasodilation. However, the effects of ATP on vessels are much more multifaceted. Recent reports of ATP inducing endothelium-independent relaxations [59, 135] and the evidence for the presence of $\mathrm{P} 2 \mathrm{X}_{1}$ receptors on vascular endothelial cells [62] increased the complexity of the effects of ATP on splanchnic circulation. ATP can induce three types of response in mesenteric arterial bed of the rat $[62,72,135,161]$ : (1) contraction, mainly mediated by smooth muscle $\mathrm{P} 2 \mathrm{X}_{1}$ receptors, (2) rapid and transient relaxation, mainly mediated by $\mathrm{P} 2 \mathrm{Y}_{2}$ receptors, and (3) slow and sustained relaxation. The mechanism responsible for this prolonged relaxation is controversial and has only very recently started to be characterized [62, 134, 135]. Guibert and co-workers [59] described an endotheliumindependent ATP-induced relaxation that was attributed to the conversion of ATP to adenosine by ectonucleotidases [59]. The first study that tried to characterize the receptor mediating this sustained possibly endothelium-independent relaxation induced by ATP was signed by Ralevic [135]. This study couldn't conclude on the purinergic receptor involved. In a second study, Ralevic [134] concluded that smooth muscle $\mathrm{P} 2 \mathrm{X}$ receptors were responsible for a biphasic response: contraction and prolonged relaxation, although a role of $\mathrm{P} 2 \mathrm{Y}$ receptors could not be excluded, since the sustained relaxation was not abolished by $\mathrm{P} 2 \mathrm{X}$ receptor dessensitization [135]. Concurrently with the studies of Ralevic, prolonged relaxation to ATP has been reported to be abolished by removal of the endothelium [161]. In a even more recent study [62], it was clearly shown that $\alpha, \beta-\mathrm{mATP}$ induced endothelium-dependent vasodilation which was also independent from the contractile effect. The preparation and methods used to remove the endothelium can explain, at least in part, the opposite results. While Ralevic used the isolated perfused mesenteric vascular bed, a preparation in which it is difficult to remove the endothelium, and endothelium removal with distilled water, Stanford and coworkers used sodium deoxycholate to endothelium-denude the arteries. In the study of Harrington and Mitchell, however, isolated rings of 2nd-order rat mesenteric arteries (mean internal diameter of $247 \mu \mathrm{m}$ ) were mounted on a wire myograph and the endothelium was physically removed by a human hair and a permanent control of the process was performed to ensure that it didn't lesion the smooth muscle cells. Moreover, it should be noticed that the study of Guibert was the only in which a vein (the rat portal vein) was used. As happens with other situations, there can be differences in the distribution and function of purinergic receptors between the arterial and the venous side of the circulation. The study of Harrington and Mitchell further evidenced, for the first time, the presence of $\mathrm{P} 2 \mathrm{X}_{1}$-like immunoreactivity in the surface of the endothelium, and concluded that the ATP-induced endothelium-dependent dilation was mainly mediated by $\mathrm{P} 2 \mathrm{X}_{1}$ receptors through the release of EDHF. In this context, it is interesting to 
Table 4 Potencies of agonists and antagonists at P2X and P2Y receptors in the splanchnic circulation

\begin{tabular}{|c|c|c|c|c|c|c|c|}
\hline Agonist/Antagonist & Slope & $\mathrm{pEC}_{50}$ & $\mathrm{EC}_{50}(\mu \mathrm{M})$ & $\mathrm{pEC}_{25}$ & $\mathrm{pEC}_{25}{ }^{\prime}$ & $\mathrm{pA}_{2}$ & Reference \\
\hline \multicolumn{8}{|l|}{$P 2 X$ receptors } \\
\hline \multirow[t]{4}{*}{$\alpha, \beta$-meATP } & $52.9( \pm 12.8)$ & & & & & & {$[20]$} \\
\hline & & & & 8.93 & & & [139] \\
\hline & & $6.68 \pm 0.13$ & & & & & [72] \\
\hline & & & $0.7 \pm 0.4$ & & & & [85] \\
\hline$\beta, \gamma$-meATP & $44.3( \pm 11.8)$ & & & & & & [20] \\
\hline \multirow[t]{4}{*}{ 2MeSATP } & $28.6( \pm 10.8)$ & & & & & & [20] \\
\hline & & & & 7.09 & & & [139] \\
\hline & & $5.71 \pm 0.22$ & & & & & [72] \\
\hline & & & $60 \pm 25$ & & & & [85] \\
\hline \multirow[t]{4}{*}{ ATP } & $31.3( \pm 5.4)$ & & & & & & [20] \\
\hline & & & & $6.13 \pm 0.10$ & & & [139] \\
\hline & & $4.94 \pm 0.15$ & & & & & [72] \\
\hline & & & $280 \pm 105$ & & & & {$[85]$} \\
\hline \multirow[t]{2}{*}{$\mathrm{ADP}$} & & & & $6.00 \pm 0.16$ & & & [139] \\
\hline & & & $254 \pm 50$ & & & & \\
\hline \multirow[t]{3}{*}{ UTP } & & & & $5.76 \pm 0.17$ & & & [139] \\
\hline & & $4.14 \pm 0.09$ & & & & & [72] \\
\hline & & & $79 \pm 6$ & & & & [85] \\
\hline Suramin & & & & & & $4.6 ; 4.89$ & [139] \\
\hline \multicolumn{8}{|l|}{$P 2 X_{1}$ receptors } \\
\hline \multirow[t]{4}{*}{$\alpha, \beta$-meATP } & & & $0.3 \pm 0.1$ & & & & [54] \\
\hline & $1.6 \pm 0.4 ; 4.2 \pm 1.5$ & & $0.4 ; 2.5$ & & & & [57] \\
\hline & $1.3 \pm 0.1$ & $5.8 \pm 0.1$ & & & & & [90] \\
\hline & & & $0.28 \pm 0.04$ & & & & [116] \\
\hline \multirow[t]{2}{*}{ ATP } & & & $196 \pm 64$ & & & & [54] \\
\hline & & & $310 \pm 30$ & & & & [116] \\
\hline \multirow[t]{2}{*}{ UTP } & & & $24 \pm 5$ & & & & [54] \\
\hline & & & $8 \pm 0.4$ & & & & [116] \\
\hline 2MeSATP & & & $30 \pm 2.7$ & & & & [116] \\
\hline $\mathrm{ATP} \gamma \mathrm{S}$ & & & $29 \pm 3$ & & & & [116] \\
\hline $\mathrm{ADP}$ & & & $1900 \pm 140$ & & & & [116] \\
\hline$\beta \gamma \mathrm{DMeATP}$ & & & $20 \pm 8$ & & & & [116] \\
\hline$\beta \gamma \mathrm{LMeATP}$ & & & $31 \pm 9$ & & & & [116] \\
\hline UDP & & & $250 \pm 3$ & & & & [116] \\
\hline \multicolumn{8}{|l|}{$P 2 Y$ receptors } \\
\hline$\beta, \gamma$-meATP & $33.0( \pm 5.5)$ & & & & & & [20] \\
\hline \multirow[t]{3}{*}{ 2MeSATP } & $40.6( \pm 8.8)$ & & & & & & {$[20]$} \\
\hline & & & $33 \pm 7$ & & & & {$[85]$} \\
\hline & & & $1.22 \pm 0.18$ & & & & [137] \\
\hline \multirow[t]{3}{*}{ ATP } & $44.4( \pm 9.3)$ & & & & & & [20] \\
\hline & & & $933 \pm 100$ & & & & {$[85]$} \\
\hline & & & $11.8 \pm 0.18$ & & & & [137] \\
\hline ADP & & & $1403 \pm 324$ & & & & {$[85]$} \\
\hline \multicolumn{8}{|l|}{$P 2 Y_{1}$ receptors } \\
\hline MRS2179 & $0.71 \pm 0.09$ & & & & & 7.1 & [105] \\
\hline $\mathrm{ADP} \beta \mathrm{S}$ & & $6.56 \pm 0.1 ; 6.29 \pm 0.31$ & & & & & [105] \\
\hline \multicolumn{8}{|l|}{$P 2 Y_{2}$ receptors } \\
\hline ATP & & & $2.8 \pm 0.9$ & & & & {$[54]$} \\
\hline \multirow[t]{2}{*}{ UTP } & & & $15 \pm 4$ & & & & {$[54]$} \\
\hline & $1.1 \pm 0.3 ; 2.2 \pm 0.3$ & & $15 ; 88$ & & & & [57] \\
\hline $\mathrm{ATP} \gamma \mathrm{S}$ & & $6.92 \pm 0.21$ & & & & & [105] \\
\hline \multicolumn{8}{|l|}{$P 2 Y_{1} / P 2 Y_{2}$ receptors } \\
\hline$\alpha, \beta$-meATP & & $7.5 \pm 0.1$ & & & & & [21] \\
\hline 2MeSATP & & $8.0 \pm 0.2$ & & & & & [21] \\
\hline 2MeSADP & & $8.2 \pm 0.2$ & & & & & [21] \\
\hline
\end{tabular}


Table 4 (continued)

\begin{tabular}{|c|c|c|c|c|c|c|}
\hline Agonist/Antagonist & Slope & $\mathrm{pEC}_{50}$ & $\mathrm{EC}_{50}(\mu \mathrm{M})$ & $\mathrm{pEC}_{25}$ & $\mathrm{pEC}_{25^{\prime}} \quad \mathrm{pA}_{2}$ & Reference \\
\hline ATP & & $6.1 \pm 0.1$ & & & & [21] \\
\hline ADP & & $6.8 \pm 0.1$ & & & & \\
\hline UTP & & $5.9 \pm 0.1$ & & & & {$[21]$} \\
\hline UDP & & $6.0 \pm 0.1$ & & & & [21] \\
\hline \multicolumn{7}{|c|}{$P 2 Y_{1} / P 2 Y_{2} / P 2 Y_{4}$ receptors } \\
\hline $\mathrm{UTP} \gamma \mathrm{S}$ & & $6.2 \pm 0.1$ & & & & [95] \\
\hline \multirow[t]{3}{*}{$\mathrm{ADP} \beta \mathrm{S}$} & & $6.0 \pm 0.1$ & & & & [95] \\
\hline & & $6.6 \pm 0.1$ & & & & [96] \\
\hline & & $6.5 \pm 0.1$ & & & & [98] \\
\hline $\operatorname{ATP} \gamma \mathrm{S}$ & & $5.8 \pm 0.2$ & & & & [95] \\
\hline \multirow[t]{3}{*}{ UTP } & & $4.8 \pm 0.2$ & & & & [95] \\
\hline & & $6.8 \pm 0.4$ & & & & [96] \\
\hline & & $6.1 \pm 0.2$ & & & & [98] \\
\hline $\mathrm{ADP}$ & & $5.3 \pm 0.2$ & & & & [95] \\
\hline \multirow[t]{3}{*}{ ATP } & & $5.4 \pm 0.2$ & & & & [95] \\
\hline & & $6.4 \pm 0.2$ & & & & [96] \\
\hline & & $5.9 \pm 0.2$ & & & & [98] \\
\hline 2MeSATP & & $5.9 \pm 0.1$ & & & & [98] \\
\hline \multirow[t]{2}{*}{ UDP } & & $3.8 \pm 0.3$ & & & & [95] \\
\hline & & $4.2 \pm 0.1$ & & & & [98] \\
\hline \multicolumn{7}{|l|}{$P 2 Y_{6}$ receptors } \\
\hline \multirow[t]{2}{*}{$\alpha, \beta$-meATP } & 2.7 & $6.1 \pm 0.2$ & & & & [95] \\
\hline & & $6.76 \pm 0.09$ & & & & [177] \\
\hline \multirow[t]{2}{*}{ ATP } & 2.4 & 4.1 & & & & [95] \\
\hline & & $4.75 \pm 0.12$ & & & & [177] \\
\hline $\mathrm{UTP} \gamma \mathrm{S}$ & & $5.3 \pm 0.2$ & & & & [95] \\
\hline UTP & & $4.74 \pm 0.15$ & & & & [177] \\
\hline $\mathrm{ATP} \gamma \mathrm{S}$ & & $4.1 \pm 0.2$ & & & & [95] \\
\hline $\mathrm{UDP} \beta \mathrm{S}$ & & & & & $7.2 \pm 0.2$ & [95] \\
\hline \multirow[t]{2}{*}{ UDP } & & & & & $2.8 \pm 0.2$ & [95] \\
\hline & & $4.97 \pm 0.11$ & & & & [177] \\
\hline
\end{tabular}

Predominant receptor considered to be involved on the basis of functional data and receptor localization studies. Values \pm S.E.M. or $95 \%$ confidence interval (in parenthesis). Slope referes to the slope of the concentration-response curve; $\mathrm{EC}_{50}$ represents the molar concentration of the agonist nedded to cause $50 \%$ of the maximum response; $\mathrm{pEC}_{50}$ and $\mathrm{pEC}_{25}$ are the negative logarithme to base 10 of the $\mathrm{EC}_{50}$ and $\mathrm{EC}_{25}$ of an agonist, respectively; $\mathrm{pEC}_{25}{ }^{\prime}$ is the negative logarithme to base 10 of the concentration of the agonist nedded to cause an increase of $25 \mathrm{mmHg}$ in blood pressure; $\mathrm{pA}_{2}$ is the negative logarithme to base 10 of the molar concentration of the antagonist that makes it necessary to double the concentration of the agonist nedded to elicit the original response.

$\beta, \gamma$-methylene ATP ( $\beta, \gamma$-meATP); 2-methylthio ATP (2MeSATP); adenosine 5'-O-3-thiotriphosphate (ATP $\gamma$ S); N6-methyl-2'-deoxyadenosine3',5'-bisphosphate (MRS2179); adenosine 5'-O-thiodiphosphate (ADP $\beta S$ ); adenosine 5'-O-3-thiotriphosphate (ATP $\gamma$ S); 2-methylthioADP (2MeSADP); uridine 5'-O-3-thiotriphosphate $(\mathrm{UTP} \gamma \mathrm{S})$; uridine 5'-O-thiodiphosphate (UDP $\beta S$ ); a, $\beta$-methylene ATP (a, $\beta$-meATP); adenosine triphosphate (ATP); adenosine diphosphate (ADP); uridine triphosphate (UTP); uridine disphosphate (UDP).

notice that renal arteries, which express $\mathrm{P} 2 \mathrm{X}_{1}$ receptors on the smooth muscle cells but not on endothelial cells, contract without subsequent vasodilation in response to $\alpha, \beta$-mATP [80].

Table 4 summarizes the information on the potencies of agonists and antagonists at $\mathrm{P} 2 \mathrm{X}$ and $\mathrm{P} 2 \mathrm{Y}$ receptors in the splanchnic circulation.

Mistry and co-workers suggested the existence of interactions between $\mathrm{P} 2 \mathrm{Y}$ receptors subtypes. They observed that in rat mesenteric artery, relaxation of smooth muscle cells and hyperpolarization of endothelial cells caused by the $\mathrm{P} 2 \mathrm{Y}_{2}$ receptor agonist $\mathrm{ATP} \gamma \mathrm{S}$ were potentiated in the presence of MRS 2179, an antagonist of $\mathrm{P}_{2} \mathrm{Y}_{1}$ receptors [105], as previously reported in non-splanchnic vessels [27, $35,128]$.

\section{Future perspectives}

This review summarized the data on the distribution and function of purinergic receptors particularly in vessels of the splanchnic circulation. The splanchnic circulation receives 
about one fourth of the cardiac output. Blood flow through the superior mesenteric artery significantly increases in a post-prandial situation [168]. In humans, the gastrointestinal tract retains its high blood flow priority, even in conditions of dynamic muscular exercise or in a pressor situation [ 45 , 185]. Thus, the dysregulation of splanchnic vascular tone is likely to contribute not only to splanchnic organs dysfunction, but also to the development of marked hemodynamic effects (e.g. altered mean arterial pressure, heart rate and total peripheral resistance) and organ failure. In intensive care patients, inadequate splanchnic perfusion is associated with increased morbidity and mortality [81].

Purinergic receptors actively participate in the regulation of splanchnic blood flow and may play an important role in clinically relevant pathological states. For instance, adenosine $A_{1}$ receptor activation seems to contribute to the improvement of splanchnic perfusion in adjunctive direct peritoneal resuscitation [193]. Purinergic receptors play an important role in the regulation of vascular and immune cell-mediated responses. These receptors trigger and mediate acute processes that affect cellular metabolism, adhesion, activation or migration. Repetitive stimulation of purinergic receptors also causes long-term reactions, like cell proliferation, differentiation and apoptosis, as seen in several chronic inflammatory states. In the cardiovascular system, purines can influence blood pressure, platelet activation, thrombosis, inflammatory processes, cardiac function and vasomotor responses $[10,11,40,50]$. The study of purinergic receptors in the splanchnic circulation is a growing field of interest. More research is needded in order to, in a near future, originate new drugs specificaly designed to treate pathologies like portal hypertension, isquemic bowel syndrome and several inflammatory states.

\section{References}

1. Abbracchio MP, Boeynaems JM, Barnard EA, Boyer JL, Kennedy C, Miras-Portugal MT, King BF, Gachet C, Jacobson KA, Weisman GA, Burnstock G (2003) Characterization of the UDP-glucose receptor (re-named here the P2Y14 receptor) adds diversity to the P2Y receptor family. Trends Pharmacol Sci 24:52-55

2. Abbracchio MP, Burnstock G, Boeynaems JM, Barnard EA, Boyer JL, Kennedy C, Knight GE, Fumagalli M, Gachet C, Jacobson KA, Weisman GA (2006) International Union of Pharmacology LVIII: update on the P2Y G protein-coupled nucleotide receptors: from molecular mechanisms and pathophysiology to therapy. Pharmacol Rev 58:281-341

3. Albino-Teixeira A, Matias A, Polonia J, Azevedo I (1991) Blockade of adenosine receptors causes hypertension and cardiovascular structural changes in the rat. J Hypertens Suppl 9:S196-197

4. Allgaier C, Greber R, Hertting G (1991) Studies on the interaction between presynaptic alpha 2-adrenoceptors and adenosine A1 receptors located on noradrenergic nerve terminals. Naunyn-Schmiedeberg's Arch Pharmacol 344:187-192
5. Atucha NM, Ortiz MC, Fortepiani LA, Ruiz FM, Martinez C, Garcia-Estan J (1998) Role of cyclic guanosine monophosphate and $\mathrm{K}+$ channels as mediators of the mesenteric vascular hyporesponsiveness in portal hypertensive rats. Hepatology (Baltimore, Md 27:900-905

6. Belardinelli L, Shryock JC, Snowdy S, Zhang Y, Monopoli A, Lozza G, Ongini E, Olsson RA, Dennis DM (1998) The A2A adenosine receptor mediates coronary vasodilation. J Pharmacol Exp Ther 284:1066-1073

7. Bo X, Burnstock G (1993) Heterogeneous distribution of [3H] alpha,beta-methylene ATP binding sites in blood vessels. J Vasc Res 30:87-101

8. Bobalova J, Mutafova-Yambolieva VN (2001) Co-release of endogenous ATP and noradrenaline from guinea-pig mesenteric veins exceeds co-release from mesenteric arteries. Clin Exp Pharmacol Physiol 28:397-401

9. Bobalova J, Mutafova-Yambolieva VN (2001) Presynaptic alpha2-adrenoceptor-mediated modulation of adenosine $5^{\prime}$ triphosphate and noradrenaline corelease: differences in canine mesenteric artery and vein. J Auton Pharmacol 21:47-55

10. Boeynaems JM, Pearson JD (1990) P2 purinoceptors on vascular endothelial cells: physiological significance and transduction mechanisms. Trends Pharmacol Sci 11:34-37

11. Brake AJ, Julius D (1996) Signaling by extracellular nucleotides. Annu Rev Cell Dev Biol 12:519-541

12. Brizzolara AL, Burnstock G (1990) Evidence for noradrenergicpurinergic cotransmission in the hepatic artery of the rabbit. $\mathrm{Br} \mathrm{J}$ Pharmacol 99:835-839

13. Brizzolara AL, Crowe R, Burnstock G (1993) Evidence for the involvement of both ATP and nitric oxide in non-adrenergic, non-cholinergic inhibitory neurotransmission in the rabbit portal vein. Br J Pharmacol 109:606-608

14. Brown CM, Collis MG (1983) Adenosine A1 receptor mediated inhibition of nerve stimulation-induced contractions of the rabbit portal vein. Eur J Pharmacol 93:277-282

15. Bucher B, Corriu C, Stoclet JC (1992) Prejunctional opioid mureceptors and adenosine A1-receptors on the sympathetic nerve endings of the rat tail artery interact with the alpha 2-adrenoceptors. Naunyn-Schmiedeberg's Arch Pharmacol 345:37-43

16. Bulloch JM, Starke K (1990) Presynaptic alpha 2-autoinhibition in a vascular neuroeffector junction where ATP and noradrenaline act as co-transmitters. Br J Pharmacol 99:279-284

17. Burgdorf C, Richardt D, Kurz T, Seyfarth M, Jain D, Katus HA, Richardt G (2001) Adenosine inhibits norepinephrine release in the postischemic rat heart: the mechanism of neuronal stunning. Cardiovasc Res 49:713-720

18. Burnstock G (1976) Purinergic receptors. J theor biol 62:491-503

19. Burnstock G, Crowe R, Kennedy C, Torok J (1984) Indirect evidence that purinergic modulation of perivascular adrenergic neurotransmission in the portal vein is a physiological process. Br J Pharmacol 82:359-368

20. Burnstock G, Warland JJ (1987) P2-purinoceptors of two subtypes in the rabbit mesenteric artery: reactive blue 2 selectively inhibits responses mediated via the P2y-but not the P2x-purinoceptor. Br J Pharmacol 90:383-391

21. Buvinic S, Briones R, Huidobro-Toro JP (2002) P2Y(1) and P2Y (2) receptors are coupled to the NO/cGMP pathway to vasodilate the rat arterial mesenteric bed. Br J Pharmacol 136:847-856

22. Carlsson PO, Olsson R, Kallskog O, Bodin B, Andersson A, Jansson L (2002) Glucose-induced islet blood flow increase in rats: interaction between nervous and metabolic mediators. Am J Physiol Endocrinol Metab 283:E457-464

23. Carmichael FJ, Saldivia V, Varghese GA, Israel Y, Orrego H (1988) Ethanol-induced increase in portal blood flow: role of acetate and A1- and A2-adenosine receptors. Am J Physiol 255: G417-423 
24. Chen RY, Chang CH, Guth PH (1994) Gastric arteriolar and venular responses to nitrogenous and nonnitrogenous vasodilating agents in the rat. Int J Microcirc Clin Exp 14:197-203

25. Chen RY, Ross G, Chyu KY, Guth PH (1993) Role of Larginine-derived nitric oxide in cholinergic dilation of gastric arterioles. Am J Physiol 265:H2110-2116

26. Chojkier M, Groszmann RJ (1981) Measurement of portalsystemic shunting in the rat by using gamma-labeled microspheres. Am J Physiol 240:G371-375

27. Chootip K, Ness KF, Wang Y, Gurney AM, Kennedy C (2002) Regional variation in $\mathrm{P} 2$ receptor expression in the rat pulmonary arterial circulation. Br J Pharmacol 137:637-646

28. Claria J, Jimenez W, Ros J, Rigol M, Angeli P, Arroyo V, Rivera F, Rodes J (1994) Increased nitric oxide-dependent vasorelaxation in aortic rings of cirrhotic rats with ascites. Hepatology (Baltimore, Md 20:1615-1621

29. Coutinho-Silva R, Parsons M, Robson T, Burnstock G (2001) Changes in expression of $\mathrm{P} 2$ receptors in rat and mouse pancreas during development and ageing. Cell Tissue Res 306:373-383

30. de Brito M, Correia J, Marques M (1998) Effect of nitric oxide on the vascular response to adenosine. Naunyn-Schmiedeberg's Arch Pharmacol 358:R258

31. de Brito MT, Canto A, Correia JH, Cunha RA, Marques MC (2002) Adenosine A(2A) receptors in portal hypertension: their role in the abnormal response to adenosine of the cranial mesenteric artery in rabbits. Br J Pharmacol 135:1324-1330

32. de Brito MT, Correia JH, Marques MC (1999) Role of endothelium on abnormal vascular responses to adenosine in portal hypertension. Br J Pharmacol 127:P106

33. De Mey J, Burnstock G, Vanhoutte PM (1979) Modulation of the evoked release of noradrenaline in canine saphenous vein via presynaptic receptors for adenosine but not ATP. Eur J Pharmacol 55:401-405

34. Diniz C, Fresco P, Leal S, Goncalves J (2004) Adenosine receptors involved in modulation of noradrenaline release in isolated rat tail artery. Eur J Pharmacol 504:17-25

35. Dol-Gleizes F, Mares AM, Savi P, Herbert JM (1999) Relaxant effect of 2-methyl-thio-adenosine diphosphate on rat thoracic aorta: effect of clopidogrel. Eur J Pharmacol 367:247-253

36. Donoso MV, Aedo F, Huidobro-Toro JP (2006) The role of adenosine $\mathrm{A} 2 \mathrm{~A}$ and $\mathrm{A} 3$ receptors on the differential modulation of norepinephrine and neuropeptide $\mathrm{Y}$ release from peripheral sympathetic nerve terminals. J Neurochem 96:1680-1695

37. Donoso MV, Steiner M, Huidobro-Toro JP (1997) BIBP 3226, suramin and prazosin identify neuropeptide Y, adenosine 5'triphosphate and noradrenaline as sympathetic cotransmitters in the rat arterial mesenteric bed. J Pharmacol Exp Ther 282:691698

38. Driessen B, von Kugelgen I, Starke K (1994) P1-purinoceptormediated modulation of neural noradrenaline and ATP release in guinea-pig vas deferens. Naunyn-Schmiedeberg's Arch Pharmacol 350:42-48

39. Drury AN, Szent-Gyorgyi A (1929) The physiological activity of adenine compounds with especial reference to their action upon the mammalian heart. J Physiol 68:213-237

40. Dubyak GR, el-Moatassim C (1993) Signal transduction via P2purinergic receptors for extracellular ATP and other nucleotides. Am J Physiol 265:C577-606

41. Dunn WR, Brock JA, Hardy TA (1999) Electrochemical and electrophysiological characterization of neurotransmitter release from sympathetic nerves supplying rat mesenteric arteries. Br J Pharmacol 128:174-180

42. Ekas RD Jr., Steenberg ML, Eikenburg DC, Lokhandwala MF (1981) Presynaptic inhibition of sympathetic neurotransmission by adenosine in the rat kidney. Eur J Pharmacol 76:301307
43. Eltzschig HK, Eckle T, Mager A, Kuper N, Karcher C, Weissmuller T, Boengler K, Schulz R, Robson SC, Colgan SP (2006) ATP release from activated neutrophils occurs via connexin 43 and modulates adenosine-dependent endothelial cell function. Circ Res 99:1100-1108

44. Enero MA, Saidman BQ (1977) Possible feed-back inhibition of noradrenaline release by purine compounds. Naunyn-Schmiedeberg's Arch Pharmacol 297:39-46

45. Eriksen M, Waaler BA (1994) Priority of blood flow to splanchnic organs in humans during pre- and post-meal exercise. Acta Physiol Scand 150:363-372

46. Evans RJ, Lewis C, Virginio C, Lundstrom K, Buell G, Surprenant A, North RA (1996) Ionic permeability of, and divalent cation effects on, two ATP-gated cation channels (P2X receptors) expressed in mammalian cells. J Physiol 497(Pt 2):413-422

47. Evans RJ, Surprenant A (1992) Vasoconstriction of guinea-pig submucosal arterioles following sympathetic nerve stimulation is mediated by the release of ATP. Br J Pharmacol 106:242-249

48. Ezzat WR, Lautt WW (1987) Hepatic arterial pressure-flow autoregulation is adenosine mediated. Am J Physiol 252:H836-845

49. Feoktistov I, Biaggioni I (1997) Adenosine A2B receptors. Pharmacol Rev 49:381-402

50. Franceschi C, Abbracchio M, Barbieri D, Ceruti S, Ferrari D, Iliou J, Rounds S, Schubert P, Schulzelohoff E, Rassendren F, Staub M, Volonte C, Wakade A, Burnstock G (1996) Purines and cell death. Drug Develop Res 39:442-449

51. Fredholm BB, Abbracchio MP, Burnstock G, Daly JW, Harden TK, Jacobson KA, Leff P, Williams M (1994) Nomenclature and classification of purinoceptors. Pharmacol Rev 46:143-156

52. Fredholm BB, AP IJ, Jacobson KA, Klotz KN, Linden J (2001) International Union of Pharmacology. XXV. Nomenclature and classification of adenosine receptors. Pharmacol Rev 53:527552

53. Gadano AC, Sogni P, Yang S, Cailmail S, Moreau R, Nepveux P, Couturier D, Lebrec D (1997) Endothelial calcium-calmodulin dependent nitric oxide synthase in the in vitro vascular hyporeactivity of portal hypertensive rats. J Hepatol 26:678-686

54. Galligan JJ, Hess MC, Miller SB, Fink GD (2001) Differential localization of $\mathrm{P} 2$ receptor subtypes in mesenteric arteries and veins of normotensive and hypertensive rats. J Pharmacol Exp Ther 296:478-485

55. Gerber JG, Guth PH (1989) Role of adenosine in the gastric blood flow response to pentagastrin in the rat. J Pharmacol Exp Ther 251:550-556

56. Gitterman DP, Evans RJ (2001) Nerve evoked P2X receptor contractions of rat mesenteric arteries; dependence on vessel size and lack of role of L-type calcium channels and calcium induced calcium release. Br J Pharmacol 132:1201-1208

57. Gitterman DP, Evans RJ (2000) Properties of P2X and P2Y receptors are dependent on artery diameter in the rat mesenteric bed. Br J Pharmacol 131:1561-1568

58. Goncalves J, Queiroz G (1993) Facilitatory and inhibitory modulation by endogenous adenosine of noradrenaline release in the epididymal portion of rat vas deferens. Naunyn-Schmiedeberg's Arch Pharmacol 348:367-371

59. Guibert C, Loirand G, Vigne P, Savineau JP, Pacaud P (1998) Dependence of P2-nucleotide receptor agonist-mediated endotheliumindependent relaxation on ectonucleotidase activity and A2Areceptors in rat portal vein. Br J Pharmacol 123:1732-1740

60. Hansen MA, Dutton JL, Balcar VJ, Barden JA, Bennett MR (1999) P2X (purinergic) receptor distributions in rat blood vessels. J Auton Nerv Syst 75:147-155

61. Hardy TA, Brock JA (1999) Effects of A1-adenosine receptor antagonists on purinergic transmission in the guinea-pig vas deferens in vitro. Br J Pharmacol 126:1761-1768 
62. Harrington LS, Mitchell JA (2004) Novel role for P2X receptor activation in endothelium-dependent vasodilation. Br J Pharmacol 143:611-617

63. Hartley SA, Kato K, Salter KJ, Kozlowski RZ (1998) Functional evidence for a novel suramin-insensitive pyrimidine receptor in rat small pulmonary arteries. Circ Res 83:940-946

64. Hiley CR, Bottrill FE, Warnock J, Richardson PJ (1995) Effects of $\mathrm{pH}$ on responses to adenosine, CGS 21680, carbachol and nitroprusside in the isolated perfused superior mesenteric arterial bed of the rat. Br J Pharmacol 116:2641-2646

65. Hirst GD, Jobling P (1989) The distribution of gamma-adrenoceptors and $\mathrm{P} 2$ purinoceptors in mesenteric arteries and veins of the guinea-pig. Br J Pharmacol 96:993-999

66. Holycross BJ, Jackson EK (1989) Adenosine-angiotensin II interactions. Part I. Role of adenosine in regulating angiotensin II-induced potentiation of noradrenergic neurotransmission and angiotensin II-induced vasoconstriction. J Pharmacol Exp Ther 250:433-441

67. Hottenstein OD, Kreulen DL (1987) Comparison of the frequency dependence of venous and arterial responses to sympathetic nerve stimulation in guinea-pigs. J Physiol 384:153-167

68. Illes P, Jackisch R, Regenold JT (1988) Presynaptic P1-purinoceptors in jejunal branches of the rabbit mesenteric artery and their possible function. J Physiol 397:13-29

69. Illes P, Rickmann H, Brod I, Bucher B, Stoclet JC (1989) Subsensitivity of presynaptic adenosine A1-receptors in caudal arteries of spontaneously hypertensive rats. Eur J Pharmacol 174:237-251

70. Jackson EK, Herzer WA, Kuan CJ (1994) Role of adenosine in noradrenergic neurotransmission during hemorrhagic hypotension. J Pharmacol Exp Ther 270:589-594

71. Jackson EK, Zhu C, Tofovic SP (2002) Expression of adenosine receptors in the preglomerular microcirculation. Am J Physiol Renal Physiol 283:F41-51

72. Juul B, Plesner L, Aalkjaer C (1993) Effects of ATP and related nucleotides on the tone of isolated rat mesenteric resistance arteries. J Pharmacol Exp Ther 264:1234-1240

73. Juul B, Plesner L, Aalkjaer C (1992) Effects of ATP and UTP on $[\mathrm{Ca} 2+] \mathrm{i}$, membrane potential and force in isolated rat small arteries. J Vasc Res 29:385-395

74. Kamikawa Y, Cline WH Jr., Su C (1980) Diminished purinergic modulation of the vascular adrenergic neurotransmission in spontaneously hypertensive rats. Eur J Pharmacol 66:347-353

75. Kennedy C, Burnstock G (1984) Evidence for an inhibitory prejunctional $\mathrm{P} 1$-purinoceptor in the rat portal vein with characteristics of the A2 rather than of the A1 subtype. Eur J Pharmacol 100:363-368

76. Kennedy C, Burnstock G (1985) Evidence for two types of P2purinoceptor in longitudinal muscle of the rabbit portal vein. Eur J Pharmacol 111:49-56

77. Khakh BS, Burnstock G, Kennedy C, King BF, North RA, Seguela P, Voigt M, Humphrey PP (2001) International union of pharmacology. XXIV. Current status of the nomenclature and properties of P2X receptors and their subunits. Pharmacol Rev 53:107-118

78. Kim M, Yoo OJ, Choe S (1997) Molecular assembly of the extracellular domain of P2X2, an ATP-gated ion channel. Biochem Biophys Res Commun 240:618-622

79. Kleppisch T, Nelson MT (1995) Adenosine activates ATPsensitive potassium channels in arterial myocytes via A2 receptors and cAMP-dependent protein kinase. Proc Natl Acad Sci U S A 92:12441-12445

80. Knight GE, Oliver-Redgate R, Burnstock G (2003) Unusual absence of endothelium-dependent or -independent vasodilata- tion to purines or pyrimidines in the rat renal artery. Kidney Int 64:1389-1397

81. Krack A, Sharma R, Figulla HR, Anker SD (2005) The importance of the gastrointestinal system in the pathogenesis of heart failure. Eur Heart J 26:2368-2374

82. Kreulen DL (1986) Activation of mesenteric arteries and veins by preganglionic and postganglionic nerves. Am J Physiol 251: H1267-1275

83. Kuan CJ, Jackson EK (1988) Role of adenosine in noradrenergic neurotransmission. Am J Physiol 255:H386-393

84. Kurz K, von Kugelgen I, Starke K (1993) Prejunctional modulation of noradrenaline release in mouse and rat vas deferens: contribution of P1- and P2-purinoceptors. Br J Pharmacol 110:1465-1472

85. Lagaud GJ, Stoclet JC, Andriantsitohaina R (1996) Calcium handling and purinoceptor subtypes involved in ATP-induced contraction in rat small mesenteric arteries. J Physiol 492(Pt 3):689 703

86. Lamont C, Vial C, Evans RJ, Wier WG (2006) P2X1 receptors mediate sympathetic postjunctional $\mathrm{Ca} 2+$ transients in mesenteric small arteries. Am J Physiol Heart Circ Physiol 291:H31063113

87. Laurent F, Hillaire-Buys D, Chapal J, Dietz S, Portet K, Cros G, Petit P, Michel A (1999) Contrasting effects of streptozotocininduced diabetes on the in vitro relaxant properties of adenosine in rat pancreatic vascular bed and thoracic aorta. Naunyn-Schmiedeberg's Arch Pharmacol 360:309-316

88. Lautt WW, Legare DJ (1986) Adenosine modulation of hepatic arterial but not portal venous constriction induced by sympathetic nerves, norepinephrine, angiotensin, and vasopressin in the cat. Can J Physiol Pharmacol 64:449-454

89. Lee FY, Albillos A, Colombato LA, Groszmann RJ (1992) The role of nitric oxide in the vascular hyporesponsiveness to methoxamine in portal hypertensive rats. Hepatology (Baltimore, Md 16:1043-1048

90. Lewis CJ, Evans RJ (2000) Comparison of P2X receptors in rat mesenteric, basilar and septal (coronary) arteries. J Auton Nerv Syst 81:69-74

91. Limberger N, Spath L, Starke K (1988) Presynaptic alpha 2adrenoceptor, opioid kappa-receptor and adenosine A1-receptor interactions on noradrenaline release in rabbit brain cortex Naunyn-Schmiedeberg's Arch Pharmacol 338:53-61

92. Lorbar M, Chung ES, Nabi A, Skalova K, Fenton RA, Dobson JG Jr., Meyer TE (2004) Receptors subtypes involved in adenosine-mediated modulation of norepinephrine release from cardiac nerve terminals. Can J Physiol Pharmacol 82:10261031

93. Luo M, Hess MC, Fink GD, Olson LK, Rogers J, Kreulen DL, Dai X, Galligan JJ (2003) Differential alterations in sympathetic neurotransmission in mesenteric arteries and veins in DOCA-salt hypertensive rats. Auton Neurosci 104:47-57

94. Machaly M, Dalziel HH, Sneddon P (1988) Evidence for ATP as a cotransmitter in dog mesenteric artery. Eur J Pharmacol 147:83-91

95. Malmsjo M, Adner M, Harden TK, Pendergast W, Edvinsson L, Erlinge D (2000) The stable pyrimidines UDPbetaS and UTPgammaS discriminate between the $\mathrm{P} 2$ receptors that mediate vascular contraction and relaxation of the rat mesenteric artery. Br J Pharmacol 131:51-56

96. Malmsjo M, Chu ZM, Croft K, Erlinge D, Edvinsson L, Beilin LJ (2002) P2Y receptor-induced EDHF vasodilatation is of primary importance for the regulation of perfusion pressure in the peripheral circulation of the rat. Acta Physiol Scand 174:301-309

97. Malmsjo M, Edvinsson L, Erlinge D (1998) P2U-receptor mediated endothelium-dependent but nitric oxide-independent vascular relaxation. Br J Pharmacol 123:719-729 
98. Malmsjo M, Edvinsson L, Erlinge D (2000) P2X receptors counteract the vasodilatory effects of endothelium derived hyperpolarising factor. Eur J Pharmacol 390:173-180

99. Malmsjo M, Erlinge D, Hogestatt ED, Zygmunt PM (1999) Endothelial P2Y receptors induce hyperpolarisation of vascular smooth muscle by release of endothelium-derived hyperpolarising factor. Eur J Pharmacol 364:169-173

100. Marques M, de Brito M, Costa P, Silva-Carvalho L (1999) Role of adenosine and nitric oxide on splanchic haemodynamics in portal hypertension. J Physiol 523P:39

101. Marston A (1977) Responses of the splanchnic circulation to ischaemia. Journal of clinical pathology 11:59-67

102. Mathie RT, Alexander B, Ralevic V, Burnstock G (1991) Adenosine-induced dilatation of the rabbit hepatic arterial bed is mediated by A2-purinoceptors. Br J Pharmacol 103:1103-1107

103. Mian R, Marshall JM (1995) The role of adenosine in mediating vasodilatation in mesenteric circulation of the rat in acute and chronic hypoxia. J Physiol 489(Pt 1):225-234

104. Michel AD, Humphrey PP (1993) Distribution and characterisation of $[3 \mathrm{H}] \mathrm{alpha}$,beta-methylene ATP binding sites in the rat. NaunynSchmiedeberg's Arch Pharmacol 348:608-617

105. Mistry H, Gitlin JM, Mitchell JA, Hiley CR (2003) Endotheliumdependent relaxation and endothelial hyperpolarization by P2Y receptor agonists in rat-isolated mesenteric artery. $\mathrm{Br} \mathrm{J}$ Pharmacol 139:661-671

106. Morato M, Pinho D, Sousa T, Guimaraes S, Moura D, AlbinoTeixeira A (2006) Pre- and postjunctional effects of angiotensin II in hypertension due to adenosine receptor blockade. Eur J Pharmacol 531:209-216

107. Morato M, Sousa T, Guimaraes S, Moura D, Albino-Teixeira A (2002) The role of angiotensin II in hypertension due to adenosine receptors blockade. Eur J Pharmacol 455:135-141

108. Morita H, Sharada T, Takewaki T, Ito Y, Inoue R (2002) Multiple regulation by external ATP of nifedipine-insensitive, high voltage-activated $\mathrm{Ca}(2+)$ current in guinea-pig mesenteric terminal arteriole. J Physiol 539:805-816

109. Msghina M, Gonon F, Stjarne L (1999) Facilitation and depression of ATP and noradrenaline release from sympathetic nerves of rat tail artery. J Physiol 515(Pt 2):523-531

110. Msghina M, Gonon F, Stjarne L (1998) Paired pulse analysis of ATP and noradrenaline release from sympathetic nerves of rat tail artery and mouse vas deferens: effects of $\mathrm{K}+$ channel blockers. Br J Pharmacol 125:1669-1676

111. Msghina M, Mermet C, Gonon F, Stjarne L (1992) Electrophysiological and electrochemical analysis of the secretion of ATP and noradrenaline from the sympathetic nerves in rat tail artery: effects of alpha 2-adrenoceptor agonists and antagonists and noradrenaline reuptake blockers. Naunyn-Schmiedeberg's Arch Pharmacol 346:173-186

112. Mulryan K, Gitterman DP, Lewis CJ, Vial C, Leckie BJ, Cobb AL, Brown JE, Conley EC, Buell G, Pritchard CA, Evans RJ (2000) Reduced vas deferens contraction and male infertility in mice lacking P2X1 receptors. Nature 403:86-89

113. Muramatsu I (1986) Evidence for sympathetic, purinergic transmission in the mesenteric artery of the dog. Br J Pharmacol 87:478-480

114. Muramatsu I, Kigoshi S, Oda Y (1990) Dissociation between sympathetic purinergic response and ATP response in the mesenteric artery of the dog. Jpn J Pharmacol 53:521-523

115. Muramatsu I, Ohmura T, Oshita M (1989) Comparison between sympathetic adrenergic and purinergic transmission in the dog mesenteric artery. J Physiol 411:227-243

116. Mutafova-Yambolieva VN, Carolan BM, Harden TK, Keef KD (2000) Multiple P2Y receptors mediate contraction in guinea pig mesenteric vein. Gen Pharmacol 34:127-136

117. Mutafova-Yambolieva VN, Keef KD (2001) Frequency dependent alpha(2)-adrenoceptor mediated modulation of excitatory junction potentials in guinea-pig mesenteric artery. Eur J Pharmacol 411:123-127

118. Nagata H, Sekizuka E, Morishita T, Tatemichi M, Kurokawa T, Mizuki A, Ishii H (1996) Adenosine A2-receptor mediates ethanol-induced arteriolar dilation in rat stomach. Am J Physiol 271:G1028-1033

119. Naito M, Yang XP, Chiba S (2004) Modification of transmitter release from periarterial nerve terminals by dipyridamole in canine isolated splenic artery. Clin Exp Pharmacol Physiol $31: 185-189$

120. Nekooeian AA, Tabrizchi R (1996) Effects of adenosine A2A receptor agonist, CGS 21680, on blood pressure, cardiac index and arterial conductance in anaesthetized rats. Eur J Pharmacol 307:163-169

121. Nicke A, Baumert HG, Rettinger J, Eichele A, Lambrecht G, Mutschler E, Schmalzing G (1998) P2X1 and P2X3 receptors form stable trimers: a novel structural motif of ligand-gated ion channels. EMBO J 17:3016-3028

122. Nori S, Fumagalli L, Bo X, Bogdanov Y, Burnstock G (1998) Coexpression of mRNAs for P2X1, P2X2 and P2X4 receptors in rat vascular smooth muscle: an in situ hybridization and RT-PCR study. J Vasc Res 35:179-185

123. Ohara N, Konishi C, Naito Y (1998) ATP-induced, P2U purinoceptor-mediated constriction of isolated, perfused mesenteric beds of the rat. Eur J Pharmacol 363:157-160

124. Olsson RA, Pearson JD (1990) Cardiovascular purinoceptors. Physiol Rev 70:761-845

125. Orre M, Pennefather JN, Story ME, Haynes JM (1996) The effects of $\mathrm{P} 2$ purinoceptor agonists on the isolated portal vein of the guinea pig. Eur J Pharmacol 316:229-236

126. Paiva MQ, Santos MJ, Albino-Teixeira A (1997) Endotheliumdependent vascular responses in 1,3-dipropyl-8-sulphophenylxanthine (DPSPX) hypertensive rats. J Pharm Pharmacol 49:7477

127. Parks DA, Jacobson ED (1985) Physiology of the splanchnic circulation. Arch Intern Med 145:1278-1281

128. Payne SJ, Benjamin IS, Alexander B (2002) Cold storage of rabbit thoracic aorta in University of Wisconsin solution attenuates P2Y(2) purine receptors. Cryobiology 44:91-102

129. Phillips JK, Hill CE (1999) Neuroreceptor mRNA expression in the rat mesenteric artery develops independently of innervation. Int J Dev Neurosci 17:377-386

130. Phillips JK, McLean AJ, Hill CE (1998) Receptors involved in nerve-mediated vasoconstriction in small arteries of the rat hepatic mesentery. Br J Pharmacol 124:1403-1412

131. Prentice DJ, Payne SL, Hourani SM (1997) Activation of two sites by adenosine receptor agonists to cause relaxation in rat isolated mesenteric artery. Br J Pharmacol 122:1509-1515

132. Queiroz G, Diniz C, Goncalves J (2002) Facilitation of noradrenaline release by adenosine $\mathrm{A}(2 \mathrm{~A})$ receptors in the epididymal portion and adenosine $\mathrm{A}(2 \mathrm{~B})$ receptors in the prostatic portion of the rat vas deferens. Eur $\mathrm{J}$ Pharmacol 448:45-50

133. Radenkovic M, Grbovic L, Pesic S, Stojic D (2005) Isolated rat inferior mesenteric artery response to adenosine: possible participation of $\mathrm{Na}+/ \mathrm{K}+-$ ATPase and potassium channels. Pharmacol Rep $57: 824-832$

134. Ralevic V (2002) The involvement of smooth muscle P2X receptors in the prolonged vasorelaxation response to purine nucleotides in the rat mesenteric arterial bed. Br J Pharmacol 135:1988-1994

135. Ralevic V (2001) Mechanism of prolonged vasorelaxation to ATP in the rat isolated mesenteric arterial bed. Br J Pharmacol 132:685-692

136. Ralevic V (2000) Sympathoinhibition by adenosine A(1) receptors, but not $\mathrm{P} 2$ receptors, in the hamster mesenteric arterial bed. Eur J Pharmacol 387:287-293 
137. Ralevic V, Burnstock G (1988) Actions mediated by P2purinoceptorsubtypes in the isolated perfused mesenteric bed of the rat. Br J Pharmacol 95:637-645

138. Ralevic V, Burnstock G (1998) Receptors for purines and pyrimidines. Pharmacol Rev 50:413-492

139. Ralevic V, Burnstock G (1996) Relative contribution of P2Uand P2Y-purinoceptors to endothelium-dependent vasodilatation in the golden hamster isolated mesenteric arterial bed. $\mathrm{Br} \mathrm{J}$ Pharmacol 117:1797-1802

140. Ramme D, Regenold JT, Starke K, Busse R, Illes P (1987) Identification of the neuroeffector transmitter in jejunal branches of the rabbit mesenteric artery. Naunyn-Schmiedeberg's Arch Pharmacol 336:267-273

141. Reichen J (1990) Liver function and pharmacological considerations in pathogenesis and treatment of portal hypertension. Hepatology (Baltimore, Md 11:1066-1078

142. Ren LM, Burnstock G (1997) Prominent sympathetic purinergic vasoconstriction in the rabbit splenic artery: potentiation by $2,2^{\prime}-$ pyridylisatogen tosylate. Br J Pharmacol 120:530-536

143. Ren LM, Nakane T, Chiba S (1994) Characteristics of the responses of isolated and perfused canine splenic arteries to vasoactive substances and to periarterially electrical stimulation. Jpn J Pharmacol 64:19-25

144. Ren LM, Nakane T, Chiba S (1996) Purinergic and adrenergic transmission and their presynaptic modulation in canine isolated perfused splenic arteries. Eur J Pharmacol 295:61-68

145. Rubino A, Ralevic V, Burnstock G (1995) Contribution of P1(A2b subtype) and P2-purinoceptors to the control of vascular tone in the rat isolated mesenteric arterial bed. Br J Pharmacol 115:648-652

146. Rubino A, Ralevic V, Burnstock G (1993) The P1-purinoceptors that mediate the prejunctional inhibitory effect of adenosine on capsaicin-sensitive nonadrenergic noncholinergic neurotransmission in the rat mesenteric arterial bed are of the A1 subtype. J Pharmacol Exp Ther 267:1100-1104

147. Rump LC, von Kugelgen I (1994) A study of ATP as a sympathetic cotransmitter in human saphenous vein. $\mathrm{Br} \mathrm{J}$ Pharmacol 111:65-72

148. Saiag B, Hillaire-Buys D, Chapal J, Petit P, Pape D, Rault B, Allain H, Loubatieres-Mariani MM (1996) Study of the mechanisms involved in adenosine-5'-O-(2-thiodiphosphate) induced relaxation of rat thoracic aorta and pancreatic vascular bed. Br J Pharmacol 118:804-810

149. Saiag B, Milon D, Allain H, Rault B, Van den Driessche J (1990) Constriction of the smooth muscle of rat tail and femoral arteries and dog saphenous vein is induced by uridine triphosphate via 'pyrimidinoceptors', and by adenosine triphosphate via $\mathrm{P} 2 \mathrm{x}$ purinoceptors. Blood Vessels 27:352-364

150. Sawmiller DR, Chou CC (1991) Adenosine is a vasodilator in the intestinal mucosa. Am J Physiol 261:G9-G15

151. Sawmiller DR, Chou CC (1992) Role of adenosine in postprandial and reactive hyperemia in canine jejunum. Am J Physiol 263: G487-G493

152. Shimokawa H, Yasutake H, Fujii K, Owada MK, Nakaike R, Fukumoto Y, Takayanagi T, Nagao T, Egashira K, Fujishima M, Takeshita A (1996) The importance of the hyperpolarizing mechanism increases as the vessel size decreases in endotheliumdependent relaxations in rat mesenteric circulation. J Cardiovasc Pharmacol 28:703-711

153. Shinozuka K, Tanioka Y, Kwon YM, Tanaka N, Kubota Y, Nakamura K, Kunitomo M (2001) Characterization of prejunctional purinoceptors inhibiting noradrenaline release in rat mesenteric arteries. Jpn J Pharmacol 85:41-46

154. Sjoblom-Widfeldt N, Gustafsson H, Nilsson H (1990) Transmitter characteristics of small mesenteric arteries from the rat. Acta Physiol Scand 138:203-212
155. Smyth L, Bobalova J, Ward SM, Keef KD, Mutafova-Yambolieva VN (2000) Cotransmission from sympathetic vasoconstrictor neurons: differences in guinea-pig mesenteric artery and vein. Auton Neurosci 86:18-29

156. Sneddon P, Burnstock G (1984) ATP as a co-transmitter in rat tail artery. Eur J Pharmacol 106:149-152

157. Sneddon P, Burnstock G (1984) Inhibition of excitatory junction potentials in guinea-pig vas deferens by alpha, beta-methyleneATP: further evidence for ATP and noradrenaline as cotransmitters. Eur J Pharmacol 100:85-90

158. Snyder DL, Wang W, Pelleg A, Friedman E, Horwitz J, Roberts J (1998) Effect of aging on A1-adenosine receptor-mediated inhibition of norepinephrine release in the rat heart. J Cardiovasc Pharmacol 31:352-358

159. Soulaymani R, Gross R, Chapal J, Loubatieres-Mariani MM (1985) [Dilator effects of adenosine on rat pancreatic vessels]. C R Seances Soc Biol Fil 179:371-374

160. Sousa T, Morato M, Albino-Teixeira A (2002) Angiotensin converting enzyme inhibition prevents trophic and hypertensive effects of an antagonist of adenosine receptors. Eur J Pharmacol 441:99-104

161. Stanford SJ, Gitlin JM, Mitchell JA (2001) Identification of two distinct vasodilator pathways activated by ATP in the mesenteric bed of the rat. Br J Pharmacol 133:825-832

162. Stjarne L, Stjarne E (1995) Geometry, kinetics and plasticity of release and clearance of ATP and noradrenaline as sympathetic cotransmitters: roles for the neurogenic contraction. Prog Neurobiol 47:45-94

163. Stoop R, Thomas S, Rassendren F, Kawashima E, Buell G, Surprenant A, North RA (1999) Contribution of individual subunits to the multimeric $\mathrm{P} 2 \mathrm{X}(2)$ receptor: estimates based on methanethiosulfonate block at T336C. Mol Pharmacol 56:973-981

164. Su C (1975) Neurogenic release of purine compounds in blood vessels. J Pharmacol Exp Ther 195:159-166

165. Surprenant A, Buell G, North RA (1995) P2X receptors bring new structure to ligand-gated ion channels. Trends Neurosci 18:224-229

166. Suzuki H (1981) Effects of endogenous and exogenous noradrenaline on the smooth muscle of guinea-pig mesenteric vein. J Physiol 321:495-512

167. Tabrizchi R, Lupichuk SM (1995) Vasodilatation produced by adenosine in isolated rat perfused mesenteric artery: a role for endothelium. Naunyn-Schmiedeberg's Arch Pharmacol 352:412-418

168. Takagi T, Naruse S, Shionoya S (1988) Postprandial celiac and superior mesenteric blood flows in conscious dogs. Am J Physiol 255:G522-G528

169. Talaia C, Hodan J, Morato M, Gonçalves J, Queiroz G (2006) Influence of purinergic $\mathrm{A} 1$ and $\mathrm{P} 2$ receptor-activation on angiotensin II-mediated facilitation of noradrenaline release in the rat mesenteric vessels. Purinergic Signalling 2:235

170. Tanaka K, Yang XP, Chiba S (2003) Purinergic and adrenergic cotransmission in canine isolated and perfused gastroepiploic arteries. Clin Exp Pharmacol Physiol 30:678-683

171. Thapaliya S, Matsuyama H, El-Mahmoudy A, Shimizu Y, Takewaki T (2003) An endothelium-derived factor modulates purinergic neurotransmission to mesenteric arterial smooth muscle of hamster. Eur J Pharmacol 461:129-137

172. Thapaliya S, Matsuyama H, Takewaki T (1999) ATP released from perivascular nerves hyperpolarizes smooth muscle cells by releasing an endothelium-derived factor in hamster mesenteric arteries. J Physiol 521(Pt 1):191-199

173. Torres GE, Egan TM, Voigt MM (1999) Hetero-oligomeric assembly of P2X receptor subunits. Specificities exist with regard to possible partners. J Biol Chem 274:6653-6659

174. Tseng CJ, Chan JY, Lo WC, Jan CR (2001) Modulation of catecholamine release by endogenous adenosine in the rat adrenal medulla. J Biomed Sci 8:389-394 
175. van der Giet M, Cinkilic O, Jankowski J, Tepel M, Zidek W, Schluter H (1999) Evidence for two different P2X-receptors mediating vasoconstriction of Ap5A and Ap6A in the isolated perfused rat kidney. Br J Pharmacol 127:1463-1469

176. Varga G, Papp M, Harsing LG Jr., Toth IE, Gaal G, Somogyi GT, Vizi ES (1984) Neuroeffector transmission of the hepatic and pancreatico-duodenal isolated arteries of the dog. Gastroenterology 87:1056-1063

177. Vial C, Evans RJ (2002) P2X(1) receptor-deficient mice establish the native $\mathrm{P} 2 \mathrm{X}$ receptor and a $\mathrm{P} 2 \mathrm{Y} 6$-like receptor in arteries. Mol Pharmacol 62:1438-1445

178. von Kugelgen I, Kurz K, Starke K (1993) Axon terminal P2purinoceptors in feedback control of sympathetic transmitter release. Neuroscience 56:263-267

179. von Kugelgen I, Starke K (1990) Evidence for two separate vasoconstriction-mediating nucleotide receptors, both distinct from the P2x-receptor, in rabbit basilar artery: a receptor for pyrimidine nucleotides and a receptor for purine nucleotides. Naunyn-Schmiedeberg's Arch Pharmacol 341:538-546

180. von Kugelgen I, Starke K (1991) Noradrenaline-ATP co-transmission in the sympathetic nervous system. Trends Pharmacol Sci $12: 319-324$

181. von Kugelgen I, Starke K (1985) Noradrenaline and adenosine triphosphate as co-transmitters of neurogenic vasoconstriction in rabbit mesenteric artery. J Physiol 367:435-455

182. von Kugelgen I, Stoffel D, Schobert A, Starke K (1996) P2purinoceptors on postganglionic sympathetic neurones. J Auton Pharmacol 16:413-416

183. von Kugelgen I, Stoffel D, Starke K (1995) P2-purinoceptormediated inhibition of noradrenaline release in rat atria. $\mathrm{Br} \mathrm{J}$ Pharmacol 115:247-254

184. Vulchanova L, Arvidsson U, Riedl M, Wang J, Buell G, Surprenant A, North RA, Elde R (1996) Differential distribution of two ATP-gated channels (P2X receptors) determined by immunocytochemistry. Proc Natl Acad Sci U S A 93:8063-8067
185. Waaler BA, Toska K, Eriksen M (1999) Involvement of the human splanchnic circulation in pressor response induced by handgrip contraction. Acta Physiol Scand 166:131-136

186. Wennmalm M, Fredholm BB, Hedqvist P (1988) Adenosine as a modulator of sympathetic nerve-stimulation-induced release of noradrenaline from the isolated rabbit heart. Acta Physiol Scand 132:487-494

187. Yang XP, Chiba S (1999) Adrenergic-purinergic interactions on vasoconstrictor responses to periarterial electric nerve stimulation in canine splenic arteries. J Auton Pharmacol 19:139-144

188. Yang XP, Chiba S (1999) Differential blocking effects of tetrodotoxin on double-peaked vasoconstrictor responses to periarterial nerve stimulation in canine isolated, perfused splenic artery. Clin Exp Pharmacol Physiol 26:784-789

189. Yang XP, Chiba S (1999) Dissociation of inhibitory effects of guanethidine on adrenergic and on purinergic transmission in isolated canine splenic artery. Eur J Pharmacol 380:5-11

190. Yang XP, Chiba S (1999) Effects of prolonged cold storage on purinergic and adrenergic components of sympathetic cotransmission in isolated canine splenic arteries. Jpn J Pharmacol 81:163-169

191. Yang XP, Chiba S (1998) Endothelium-released adenosine triphosphate contributes to vasoconstrictor responses to periarterial nerve stimulation in isolated, perfused canine splenic arteries. Heart Vessels 13:256-261

192. Yang XP, Chiba S (1998) Pharmacological analysis of the double peaked vasoconstrictor responses to periarterial electric stimulation. J Auton Pharmacol 18:343-347

193. Zakaria el R, Li N, Garrison RN (2007) Mechanisms of direct peritoneal resuscitation-mediated splanchnic hyperperfusion following hemorrhagic shock. Shock (Augusta, Ga 27:436-442

194. Zhao G, Linke A, Xu X, Ochoa M, Belloni F, Belardinelli L, Hintze TH (2003) Comparative profile of vasodilation by CVT3146, a novel A2A receptor agonist, and adenosine in conscious dogs. J Pharmacol Exp Ther 307:182-189 